\title{
البرناهج الرابع
}

\section{دعم ذوى الاحتياجات الخاصة من المعاقين والموهوبين والفائقين}

\author{
إعداد

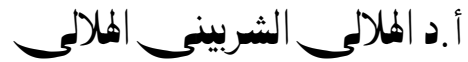 \\ أستاذ التخطيط التربوي والإدارة التعليمية بجامعة المنصورة \\ ووزير التربية والتعليم والتعليهم الفني السـابق لجريق
}

\section{مجلة بحوث التربية النوعية ـ جامعة المنصورة}

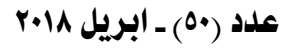

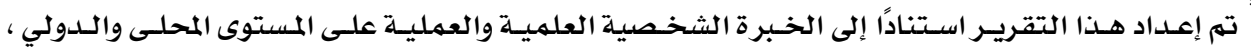

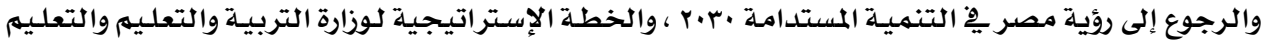

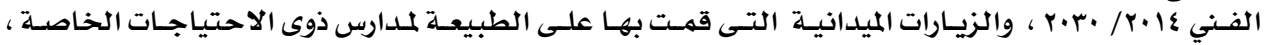

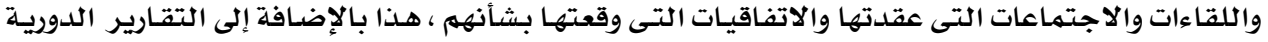

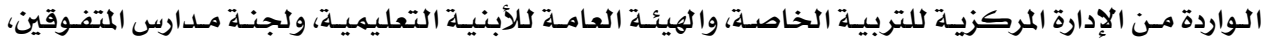

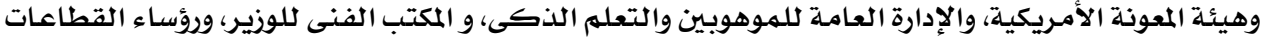

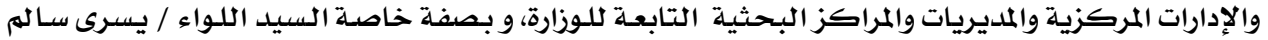

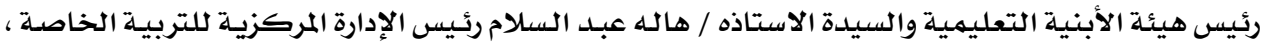

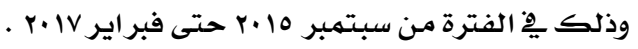




\section{البرناهج الرابع}

\section{دعم ذوى الاحتياجات الخاصة هن المعاقين والموهوبين والفائقين}

إعداد

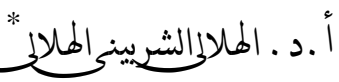

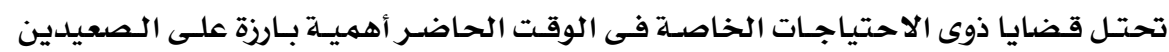

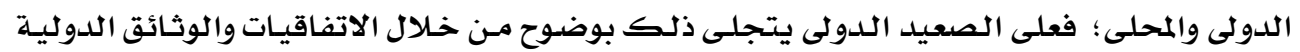

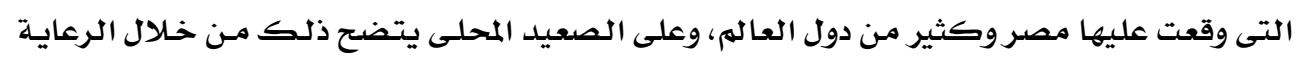

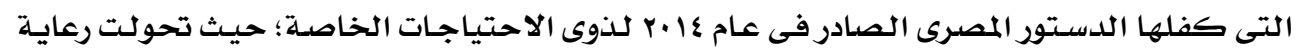

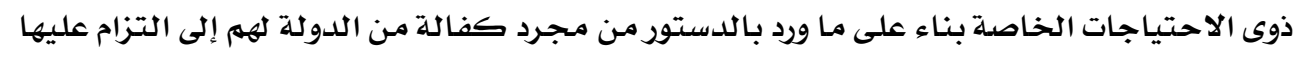

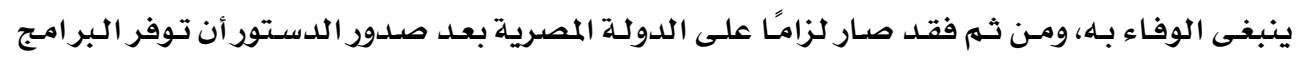

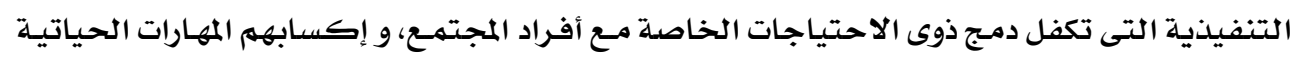

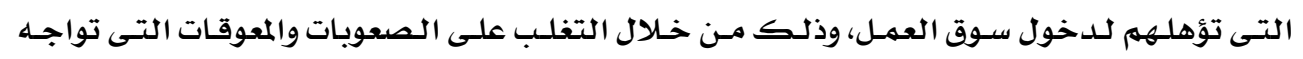

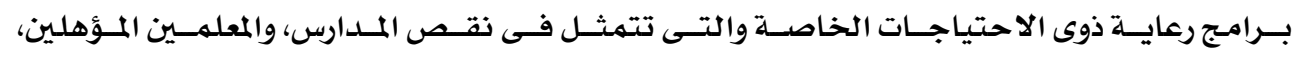

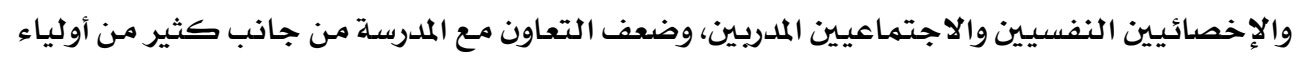

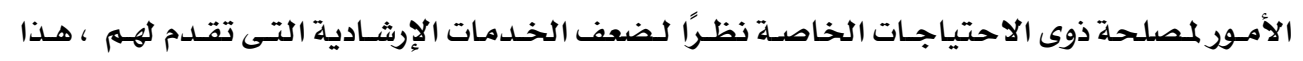

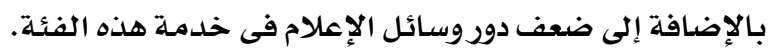

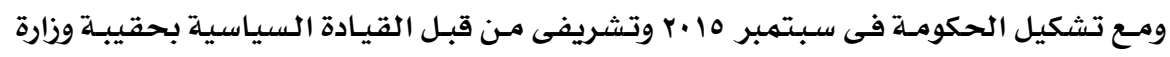

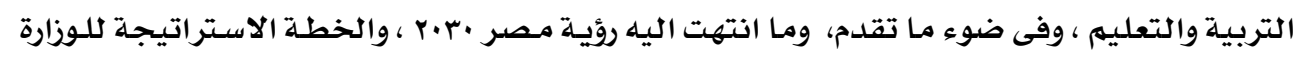

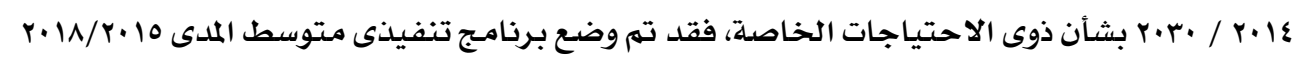

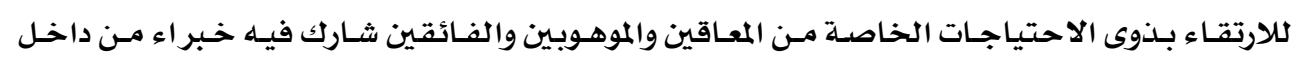

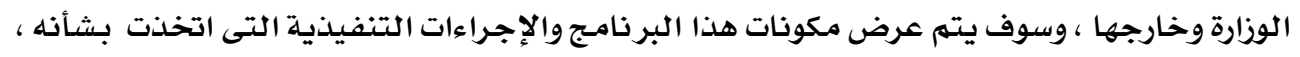

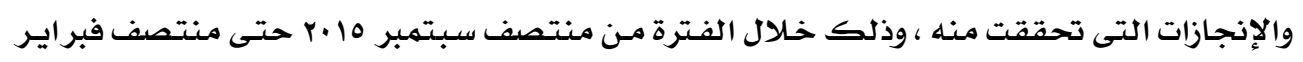


تضمن هذا البرناميج بـالنسبية لكل فئة من فئات ذوى الاحتياجات الخاصة العناصر والآليات

الرئيسية التتالية:

ا ـ فيما يتعلق بذوى الاحتياجات الخاصة من أصحاب الإعاقات تضمن البر نامج:

$$
\text { دعم التتمية المهنية لمعلمى وإخصائى ذوى الإعاقة . }
$$

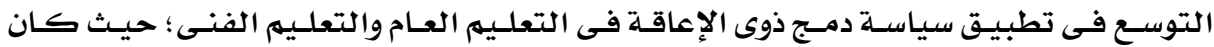

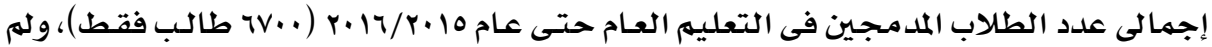

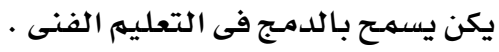

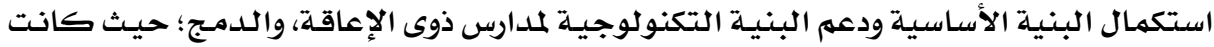

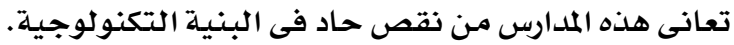

دعم الأنشطة التربوية لذوى الإعاقة، حيث إن الأنشطة التربويـة الصفية منها والكلاصفية على مئى

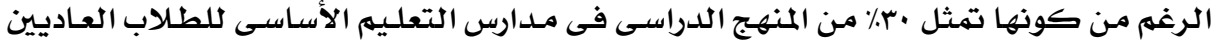

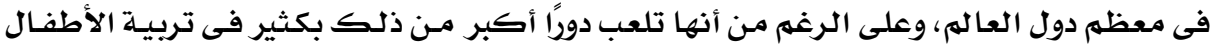

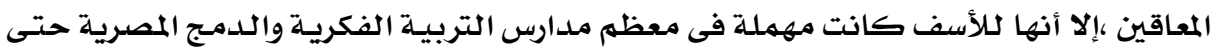

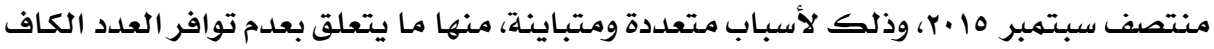

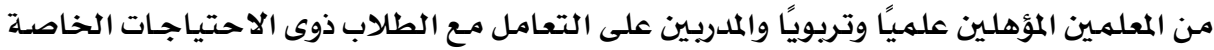

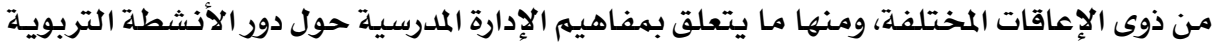

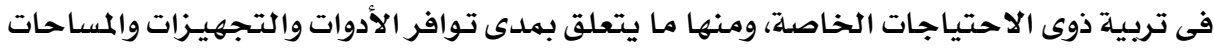

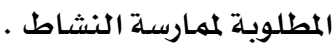
فتح عدد r فصول لذوى الإعاقة البصرية بمـحافظة البحر الأحمر . فتح عدد IV قاعة رياض أطفال بمدار النور للمكفوفين سنويًا.

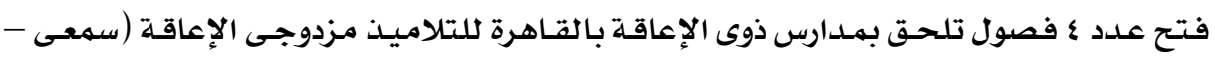
بصرى) كتجرية وفى حالة نجاحها يتم التوسع فيها ونشرها فى في باقى المحافظات.

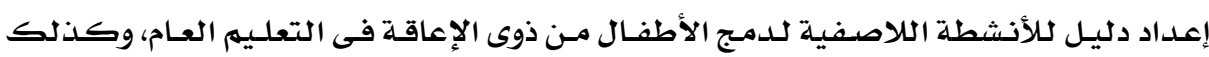

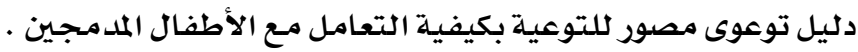
إعداد معايير ومؤشـرات مناهج ذوى الإعاقة السمعيلة فى اللغـة العربيـة، والدراسـات الاجتهاعيـة،

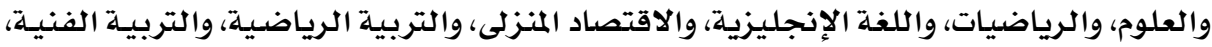

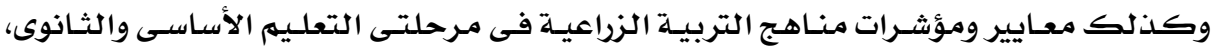




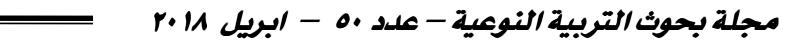

ومناهج ذوى الإعاقة البصريـة فى اللغة الفرنسية، ومعايير ومؤشرات منهج اللغـة الإنجليزيـة فى إنى

رياض الأطفال، ووضع وثيقة التربية الخاصة فى شكلها النهائى (بصرى - سمعى - ذ ذهني).

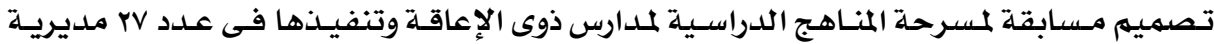
تعليمية سنويًا.

تصميم برنامجج توعوى لرفع الوعى بالإعاقة والمعاقين لدى المسئولين، وأوليـاء الأمـور، والطلاب ،

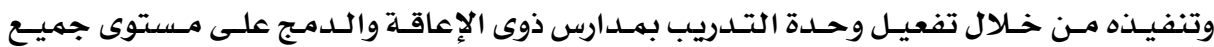

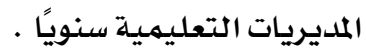

تنفيذ البطولة المدرسية لمدارس ذوى الإعاقة باستهداف حوالى .... ب طالب وطالبة سنويًا. r. وفيما يتعلق بالموهوبين والثائقين تضمن البرنامج:

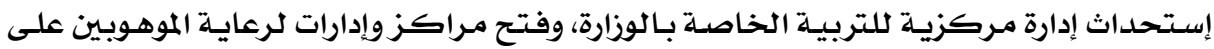

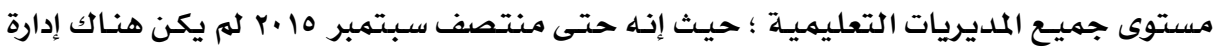

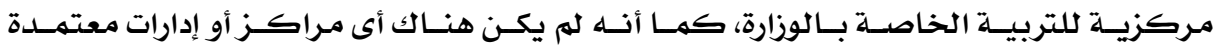

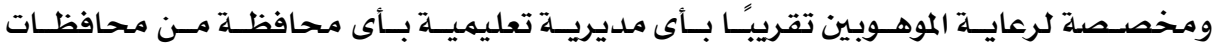

الجمهوريـة.

تطوير وتحديث طرق اكتشاف ورعاية الموهوبين، ورفع كفاءة المسئولين عنهم.

دعم الأنشطة التربوية المختلفة للموهوبين.

إعداد وطباعة دليل إرشادى لدعم الموهبة والتفوق وتوزيعه على جميع المديريات التعليميلة .

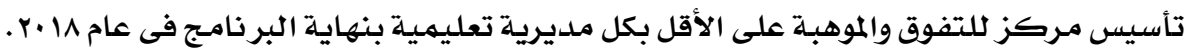

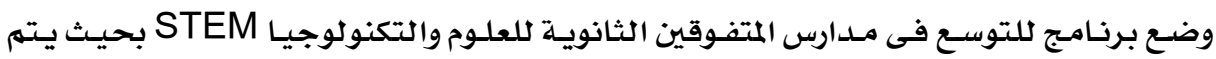

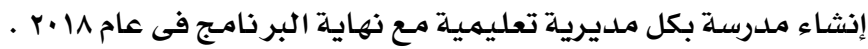

وقد ترتب على هذا البر نامج اتخاذ مجموعة من الإجراءات وتحقيق مجموعة من الإنجازات

وذلك على النحو التالى : وتئي

ثانياً: الإجراءات التى اتهذت والإنهازات التى تهققت هن البرناهج هتى هنتصف فبرايـر

P.IV

ا - بالنسبة للذوى الإعاقة: ته اتخاذ الإجرائات وتحقيق الإنجازات التالية:

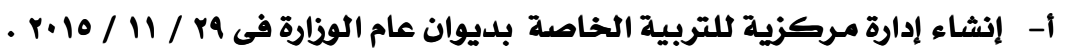

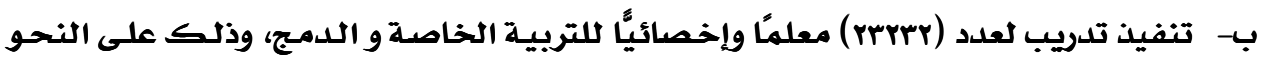

التتالي:

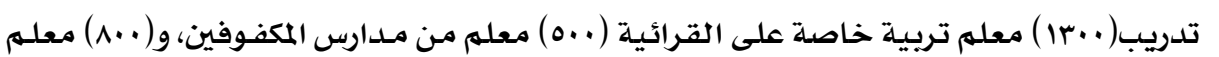

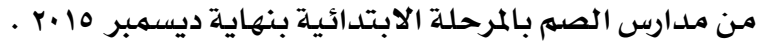




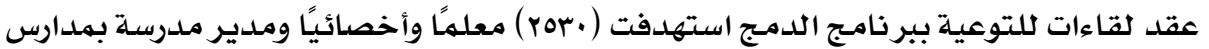

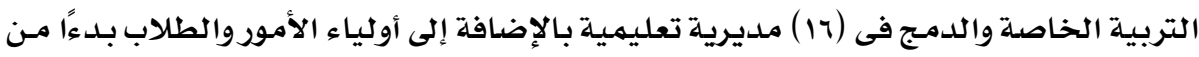

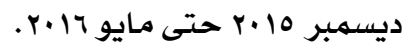

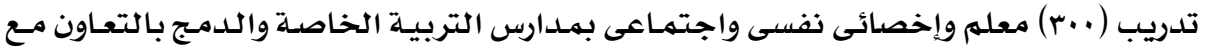

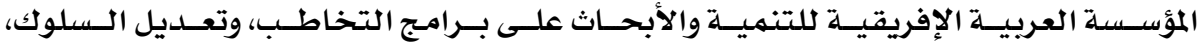

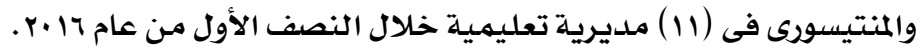

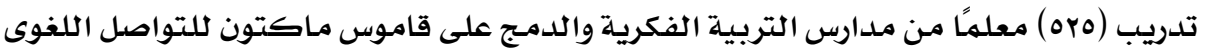

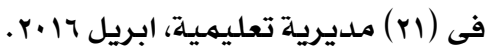

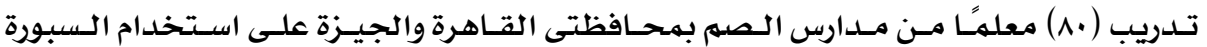
التفاعلية، مارس 17 •r.

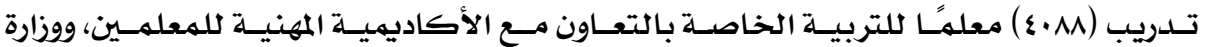

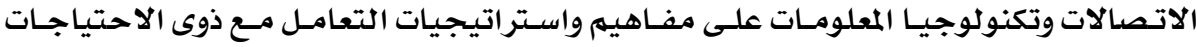

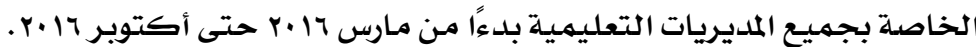

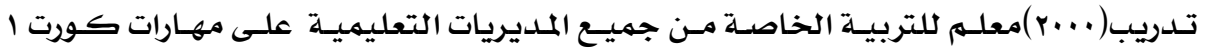

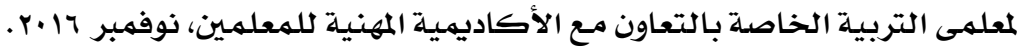

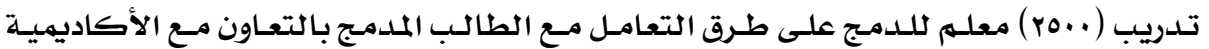

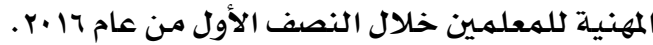

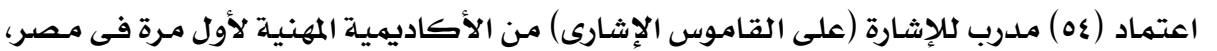

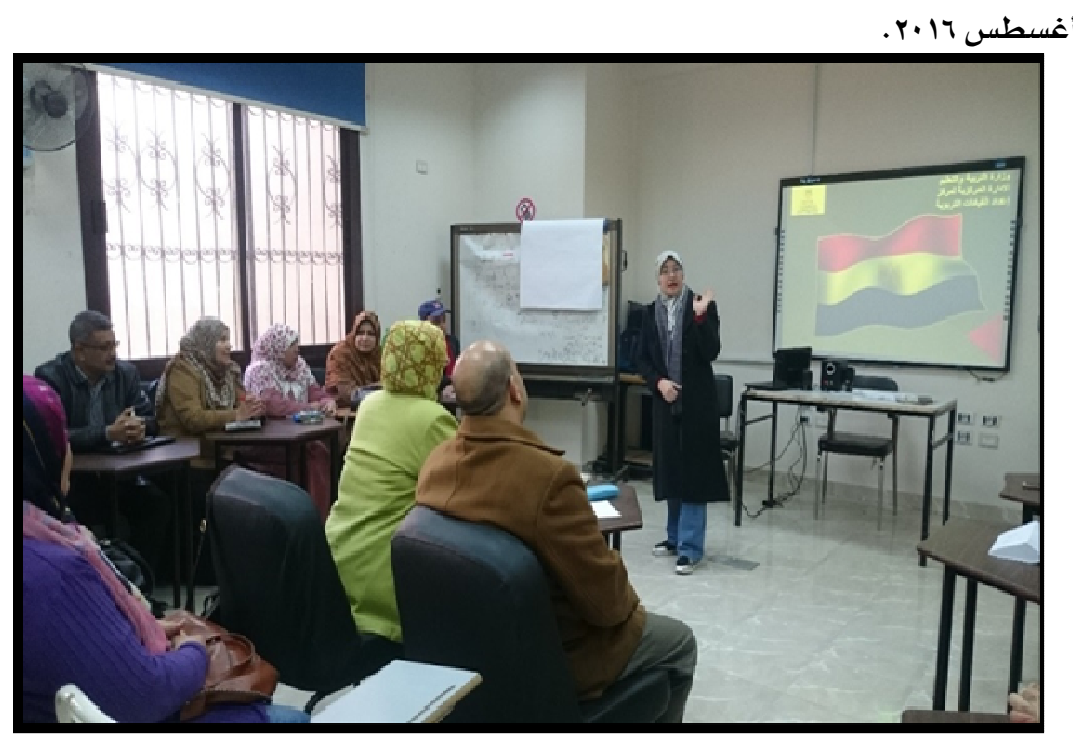




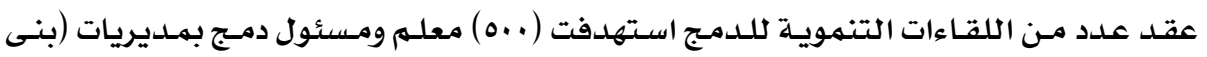

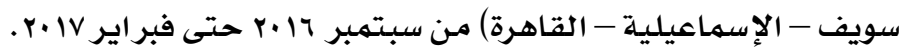

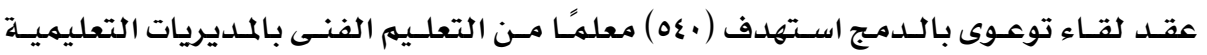

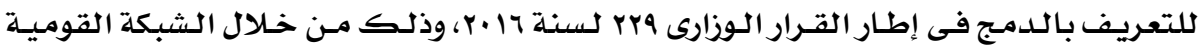

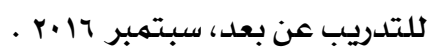

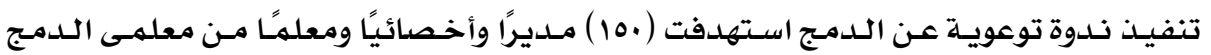

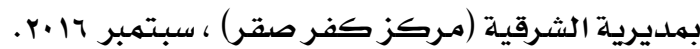

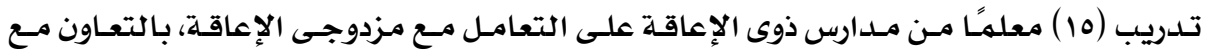

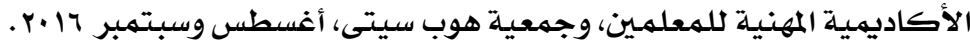

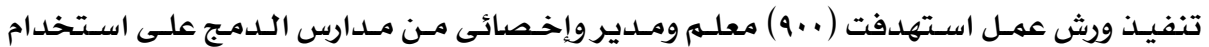

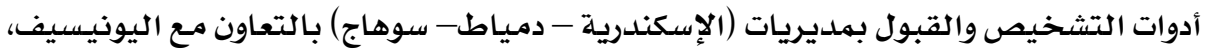

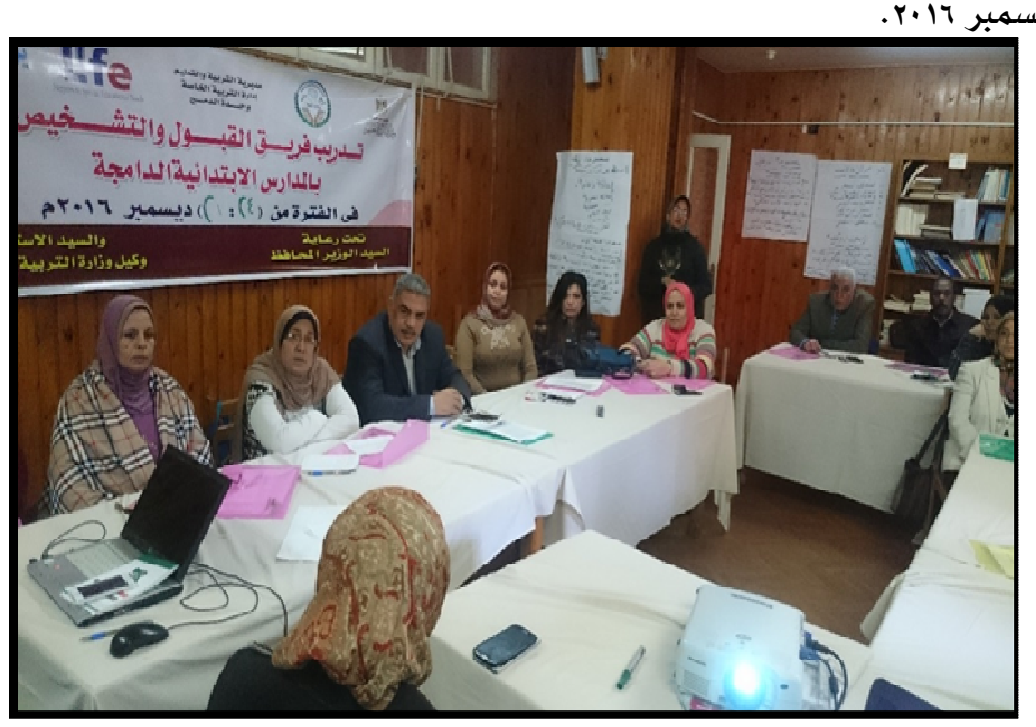

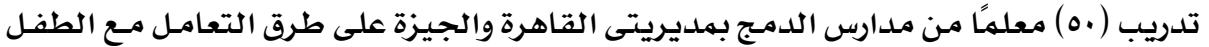

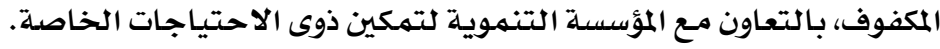

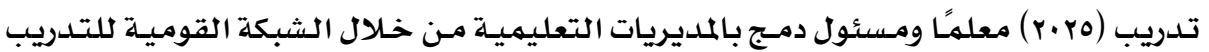

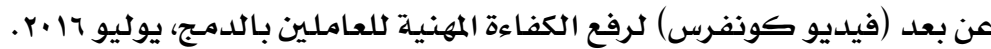

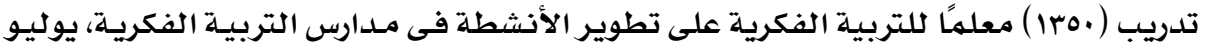
$. r+17$ تنفيذ لقاء توعوى بالدمـج استهدف ( . . ) معلم من مديرى وموجهى التعليهم الفنسى عن طريق

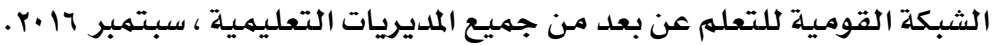


تنفيـذ ورثـة عمـل لتطـوير ودعهم مـدارس التربيـة الفكريـة بالتعـاون مـع جمعيـة الأسـر المتآلفـة

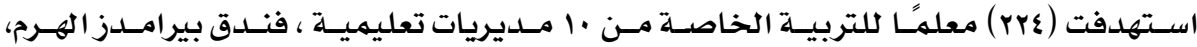

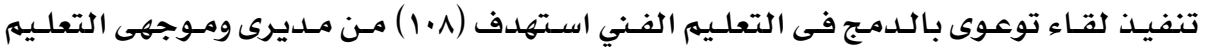

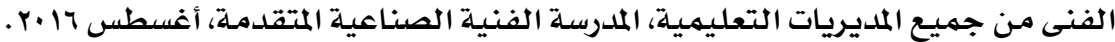

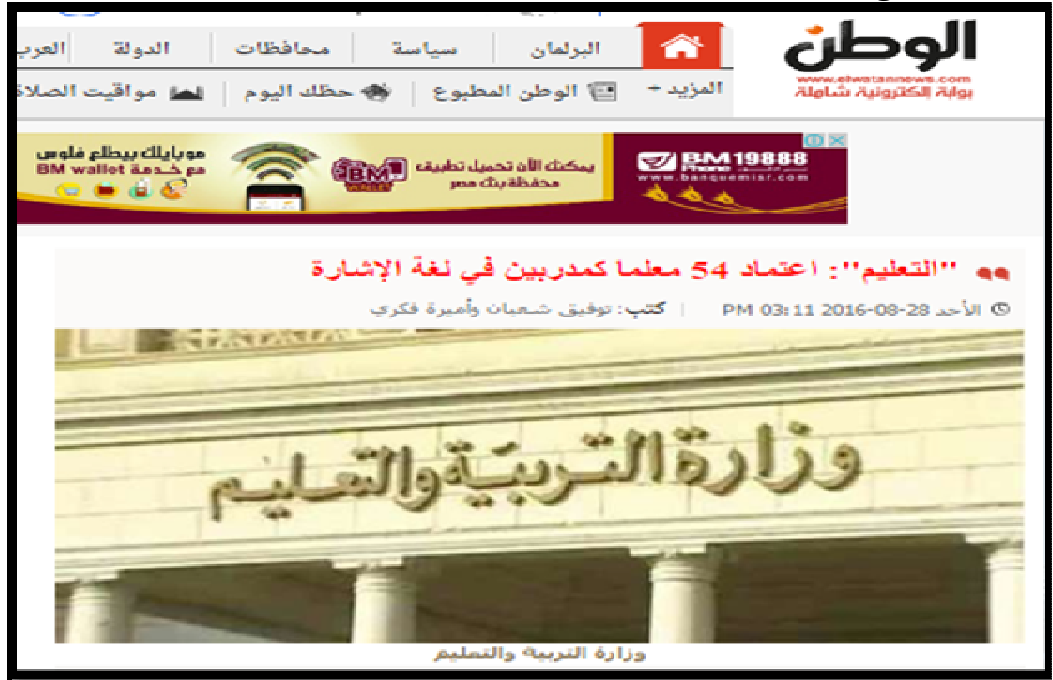

•تنفيـذ حملـتين للتوعيـة بالـدمـج التعليهـى بالتعـاون مـع الجمعيـة التعاونيـة للمعاهـد القوميـة استهدافتا (vo) معلمًا للدمج بمدارس المعاهد القومية المتخصصدة بمدريتى القاهرة والإسكندريـة

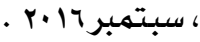

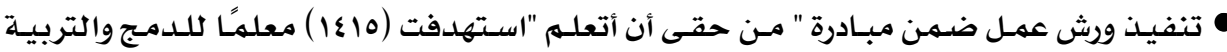

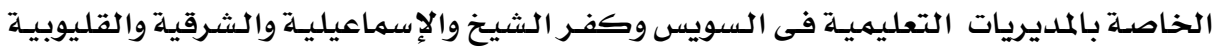

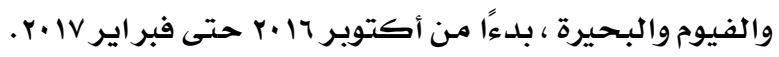

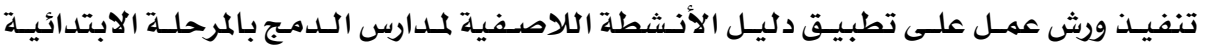

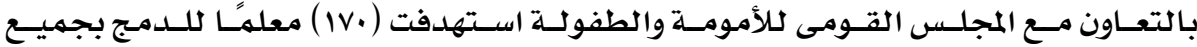

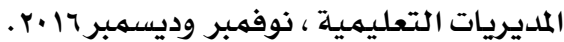

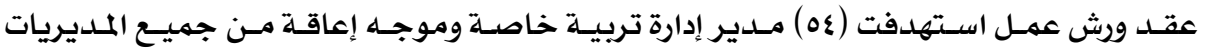

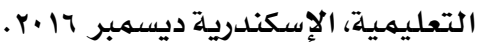

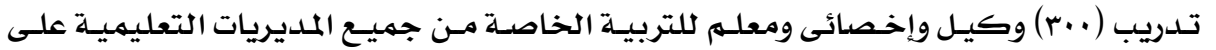

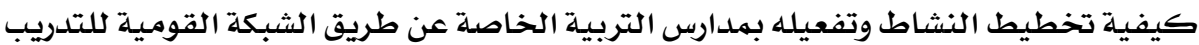

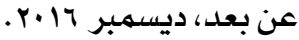




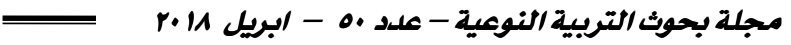

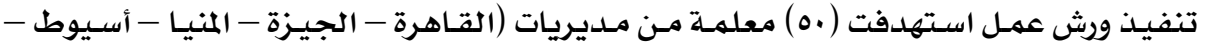

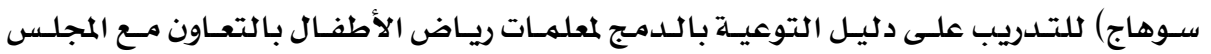

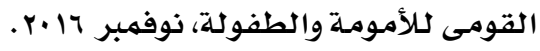

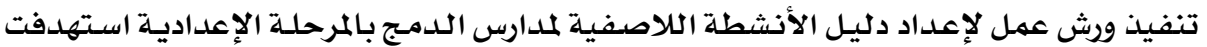

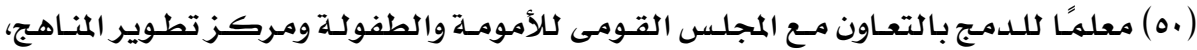

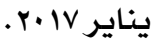

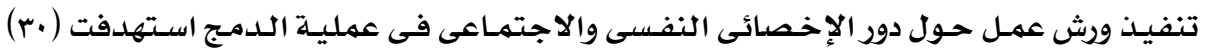

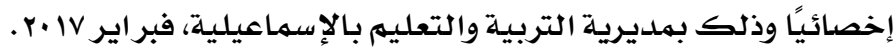

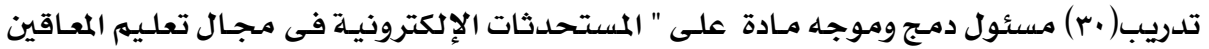

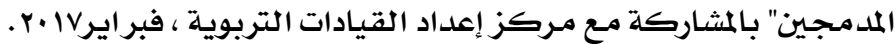

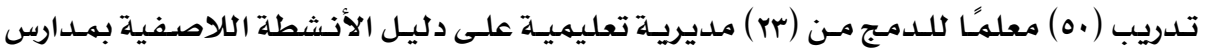

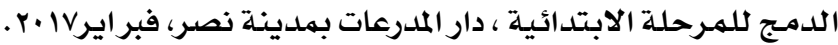

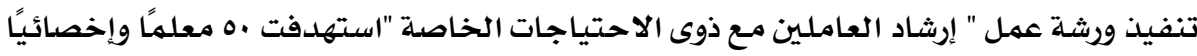

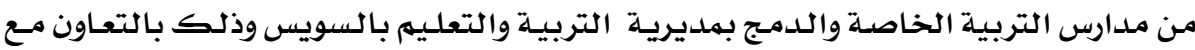

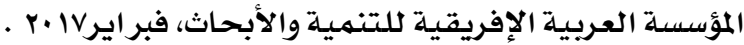

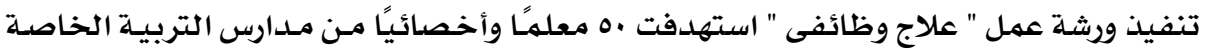

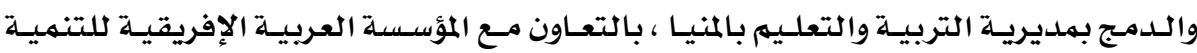

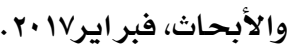

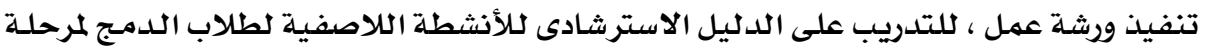

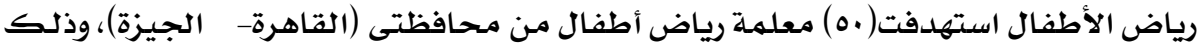

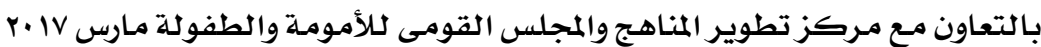

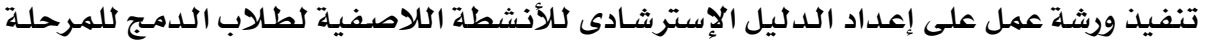

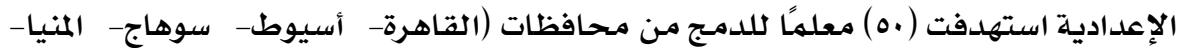

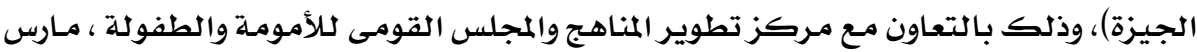




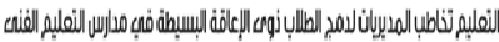

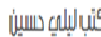

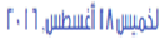

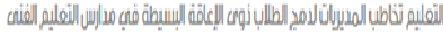

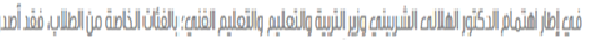

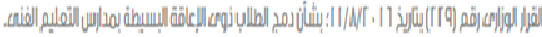

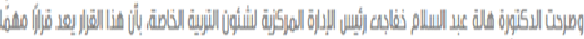

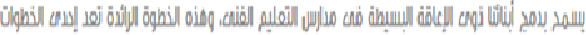

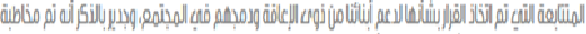

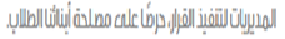

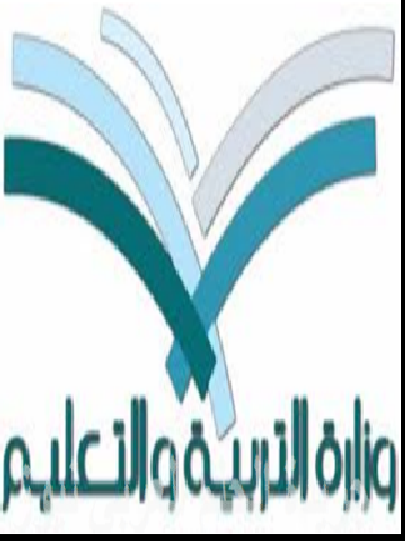

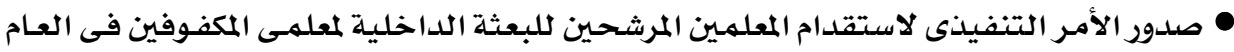

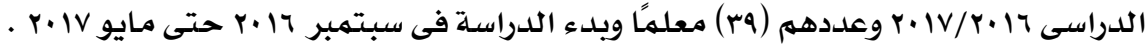
ج- التوسـع فى تطبيق سياسة الدمج، وتطوير المناهج الدراسية لذوى الإعاقة وطلاب الدمج؛؛ حيث تم

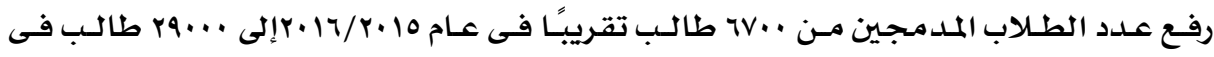

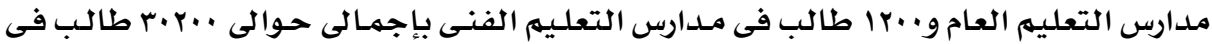

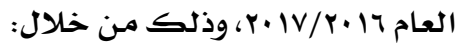

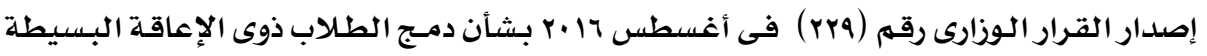

$$
\text { بمدارس التعليهم الفنى . }
$$

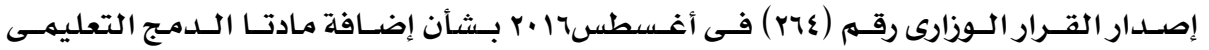

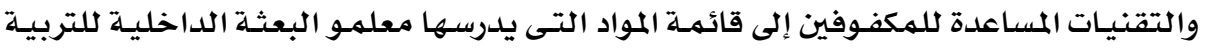

$$
\text { الخاصدة (مكفوفين). }
$$

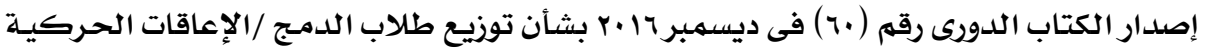
والمكفوفين بفصول الدور الأرضى بالمدارس ل

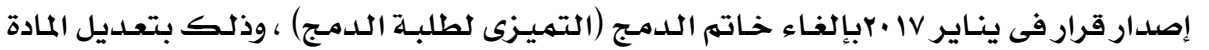

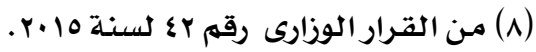



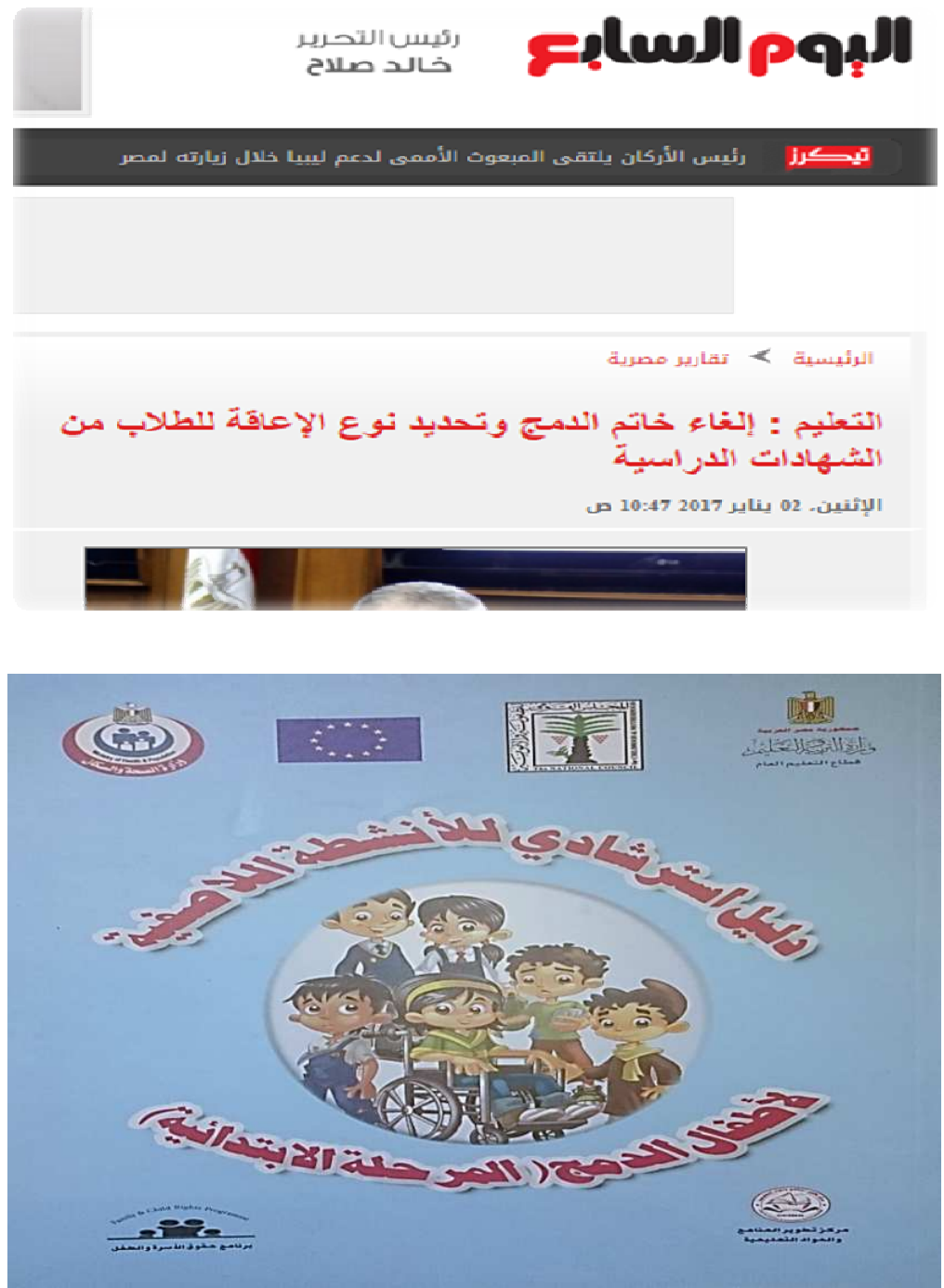

وضع دليل للأنشطة اللاصفية لطلاب الدمـج (المرحلة الابتدائية) وتنفيذ ورث عمل تنويرية

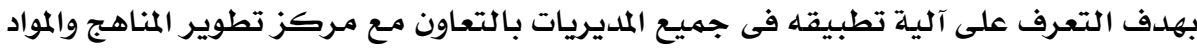

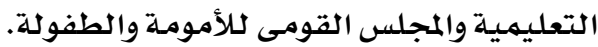
• وضع خطة مستقبلية لدمـج الطلاب ذوى الإعاقة البسيطة في التعليم العام بالتعاون مـع هيئة

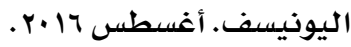

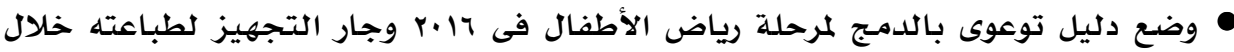
مايوV|+r. 


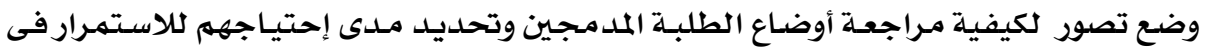

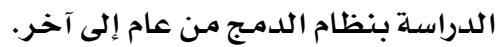

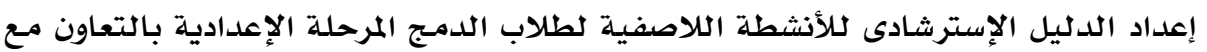

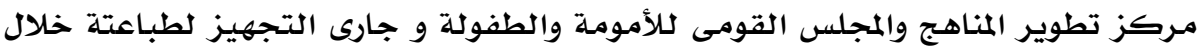

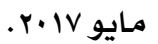
وضع وثيقة معايير لمناهج مزدوجى الإعاقة (صمى ومكفوفين) بالتعاون مـع مركز تطوير المناهج

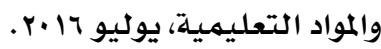

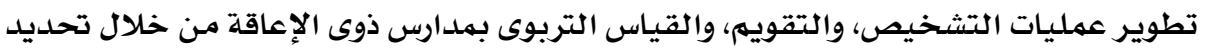

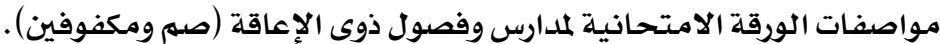

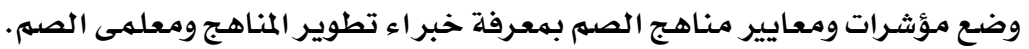

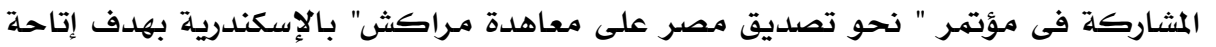

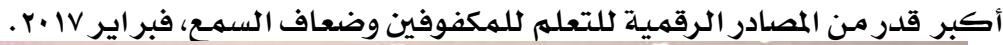

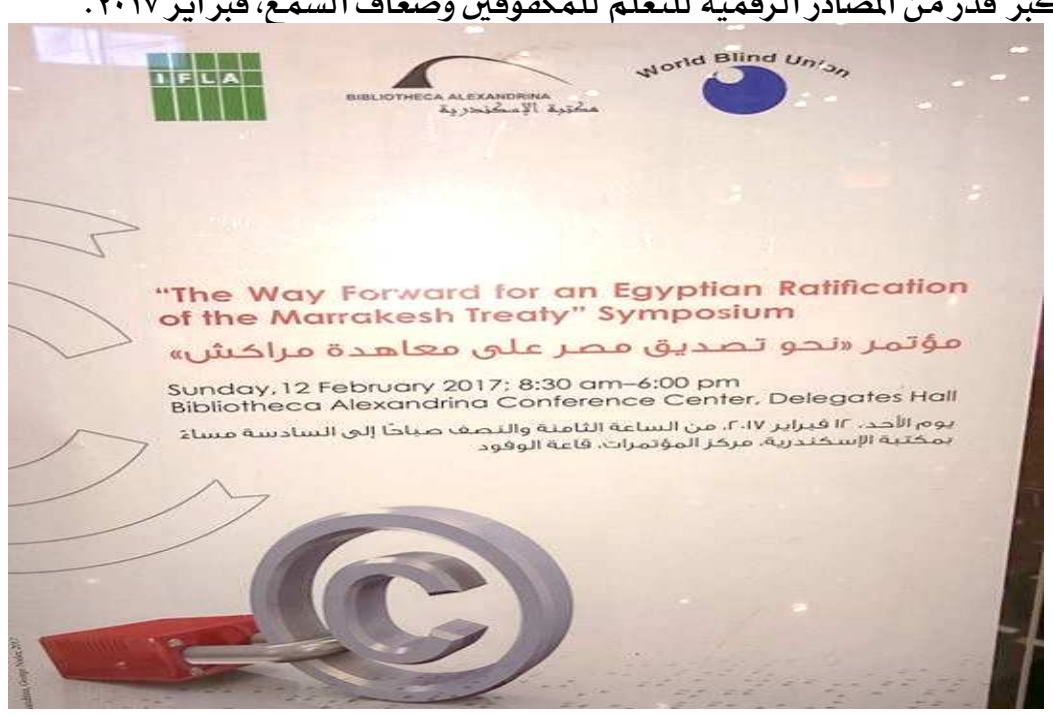

د- دعم البنية التكنولوجية لمدارس ذوى الإعاقة، والدمج؛ حيث تم :

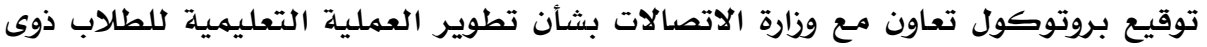

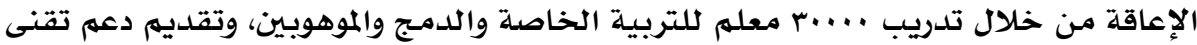

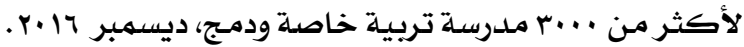




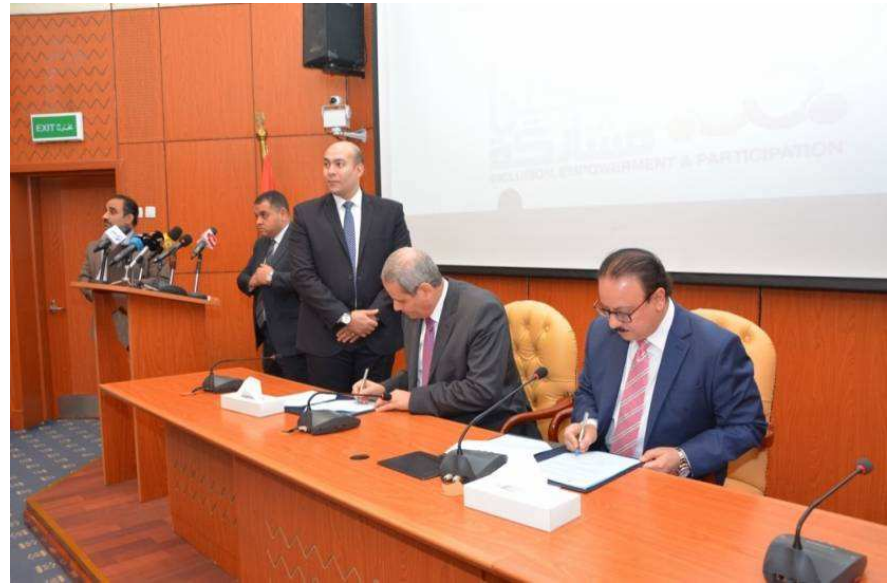

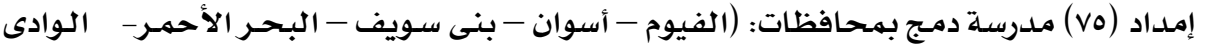

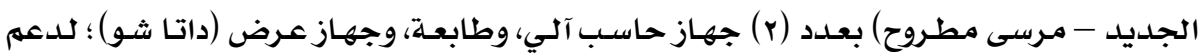

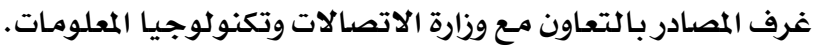

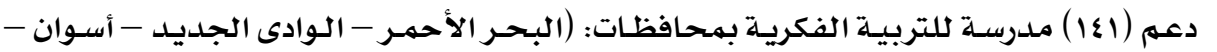

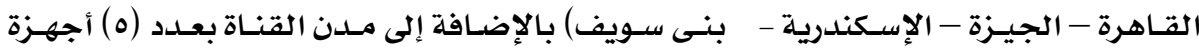

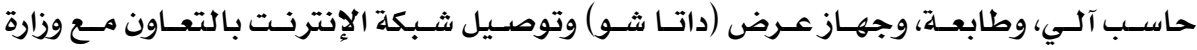
الاتصالات وتكنولوجيا المعلومات.

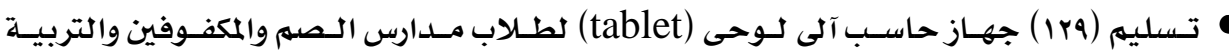

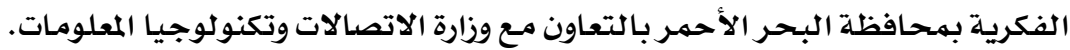

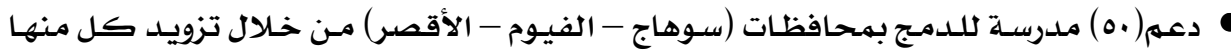

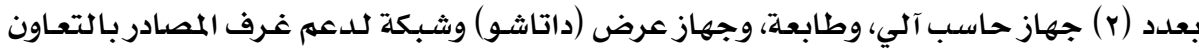

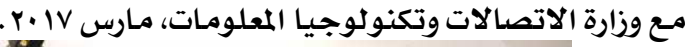

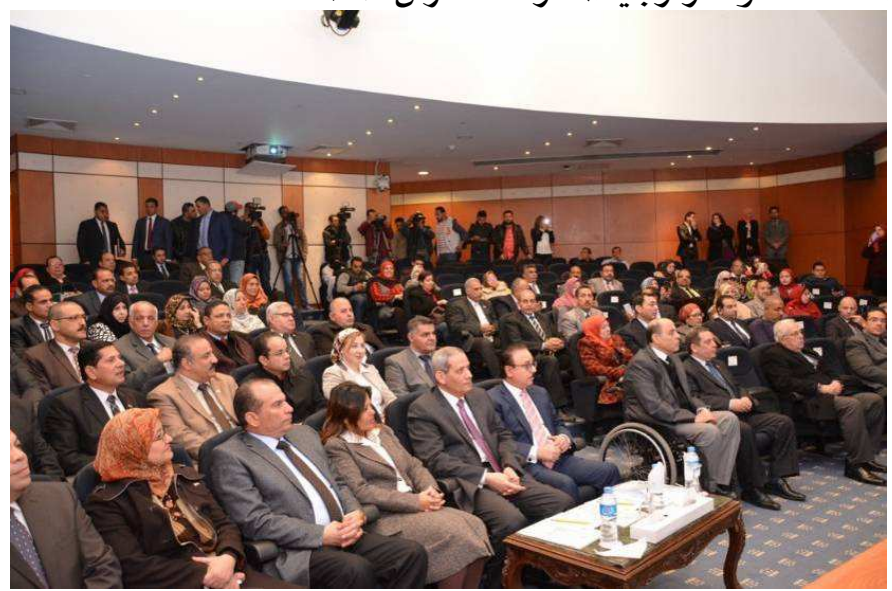




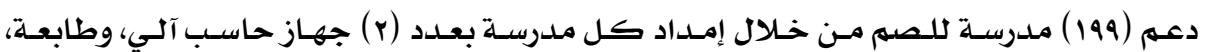

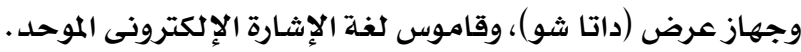

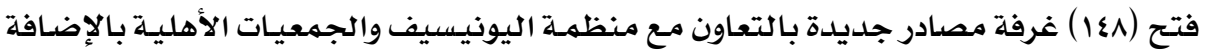

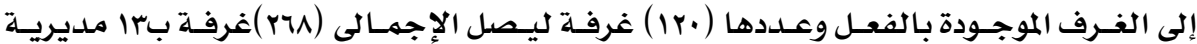

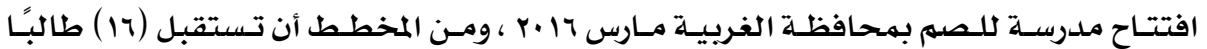

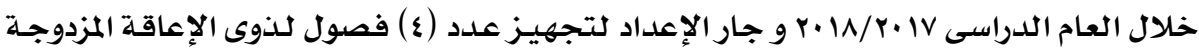

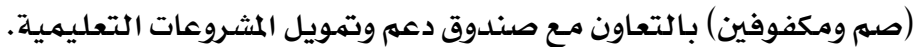

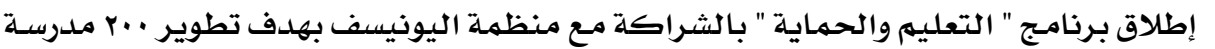

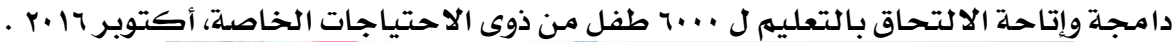

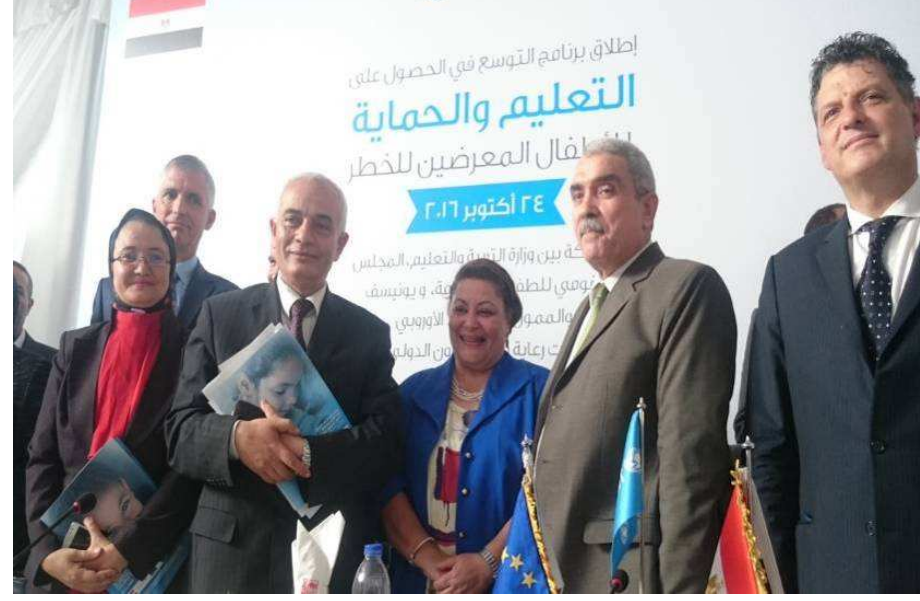

هـ- دمم الأنشطة التربوية لذوى الإعاقة؛ حيث تم :

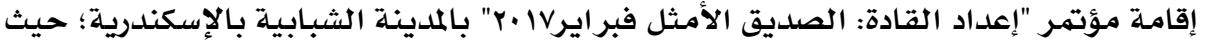

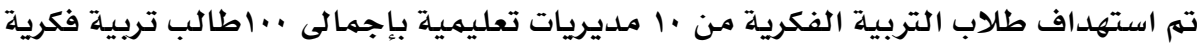

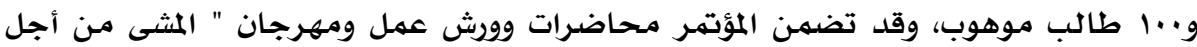
الصداقة " بالتعاون مـع جمعية الأسرة المتآلفة. 


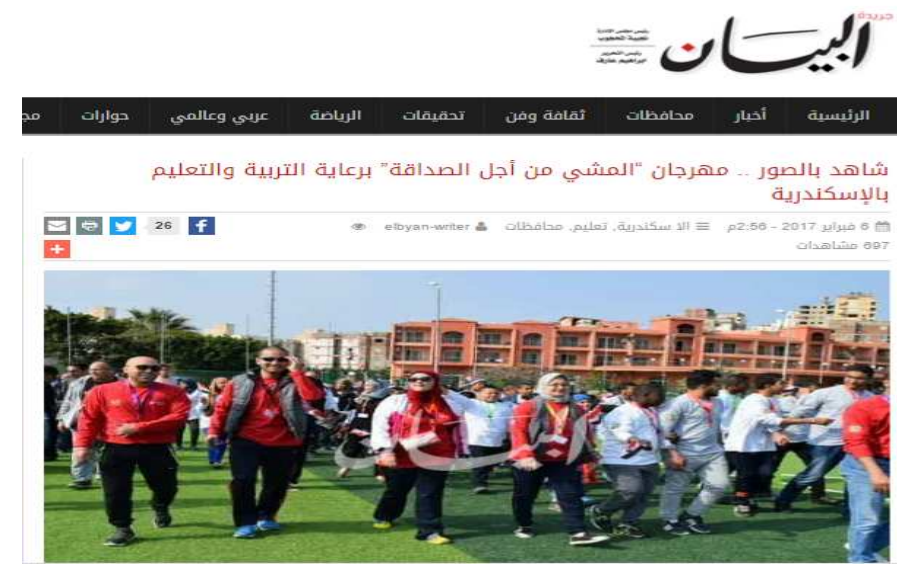

هإقامة ملتقى الأنشطة لمدارس التربية الفكرية المطورة بالمدينـة الشبابية بالإسـكندريـة؛ حيث تم

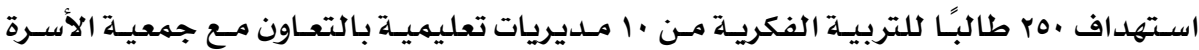

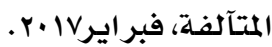

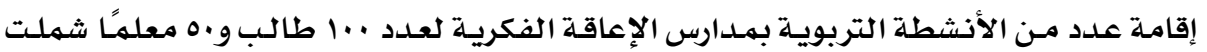

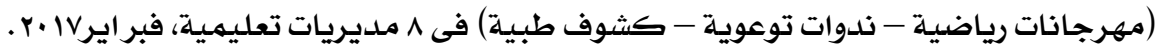

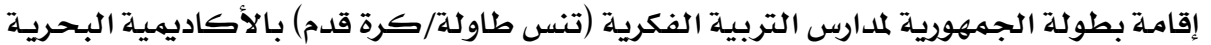

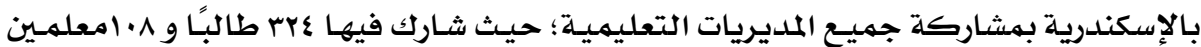

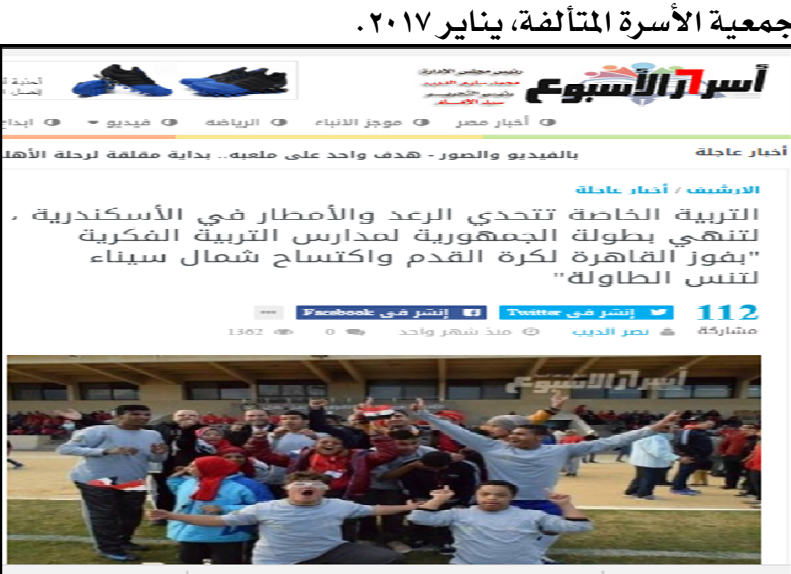

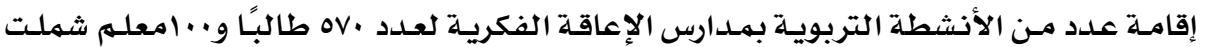

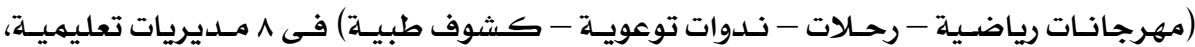

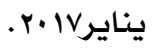

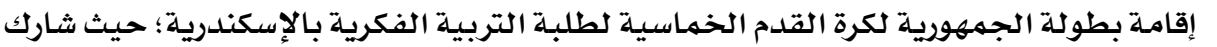

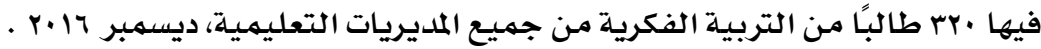




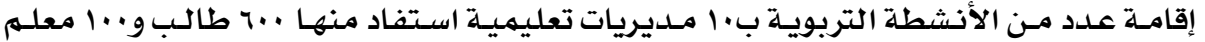

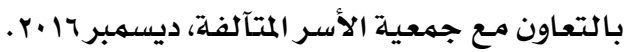

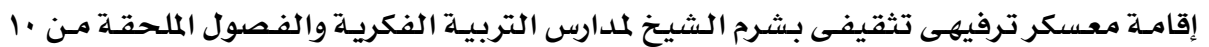

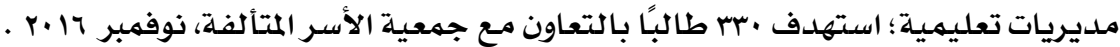
إقامـة دورى كرة القدم لطـلاب التربيـة الفكريـة على مستوى الجمهوريـة، بالتعـاون مـع جمعيـة

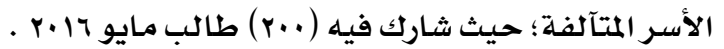

إقامـة دورى كرة القدم الخماسـيـة للصهم وضـعاف السهـع بالإسـكندريـة ؛ حيـث شـارك فيـه (YIV)

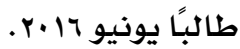
تنفيـذ مـسـابقة سـنويـة لمسرحة المنـاهـج الدراسـيـة فى جميـع المديريـات التعليميـة بهـدارس ذوى الإععاقة. تنفيذ ورث عمل نجـارة ونسيـج وبـامبو اسـتهدفت ( •ه ) طالبًا مـن طلبـة مـدارس التربيـة الفكريـة بهحافظة القاهرة.

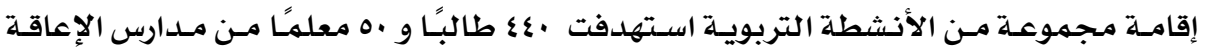

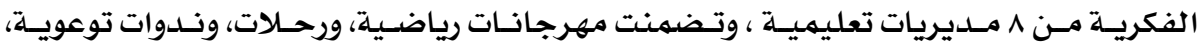
وكشوف طبية بالتعاون مـع جمعية الأسر المتألفة، نوفمبر 17 •r . إطلاق مبادرة " أنـا أصسم مـن حقى أن تفههنى " ؛ حيـث استهـدفت . .ب موظف مـن دواوين كل

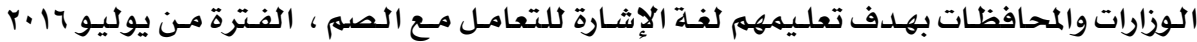

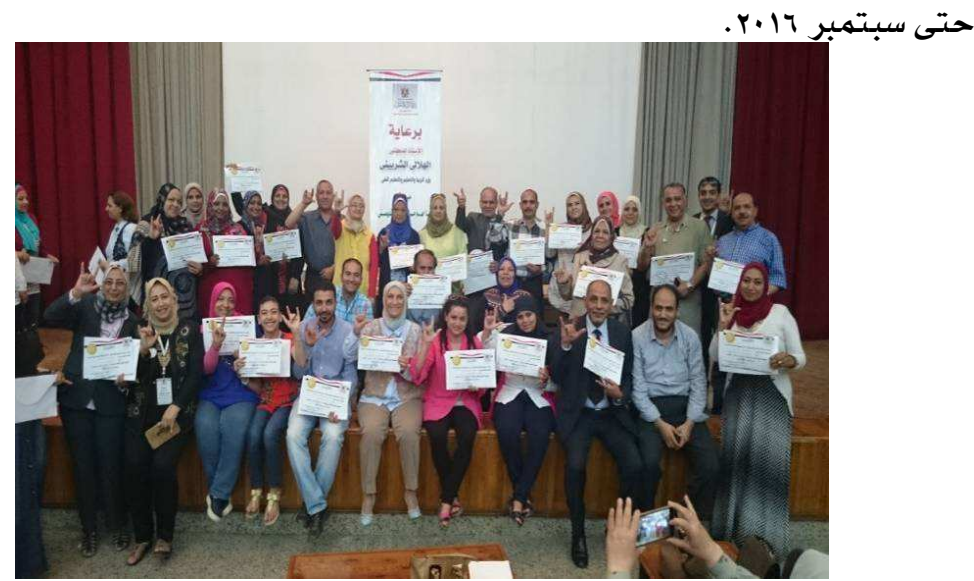

r- بالنسبة للهوهوبين والثائقين: تم اتخاذ الإجراءات وتحقيق الإنجازات التالية :

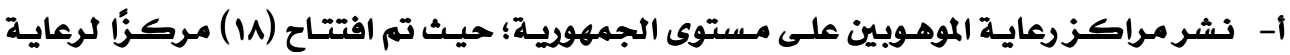
الموهوبين على مستوى الجمهوريـة فى II محافظلة حتى نهايـة شهر فبراير IV +r، على النحو 


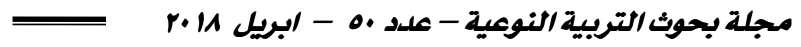

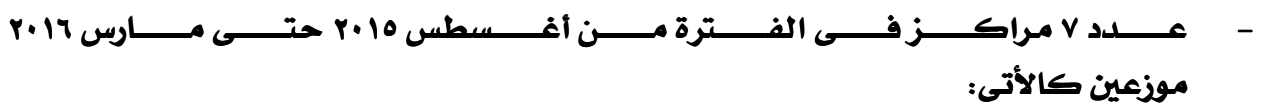

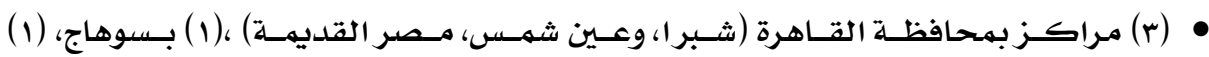

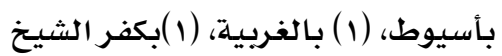

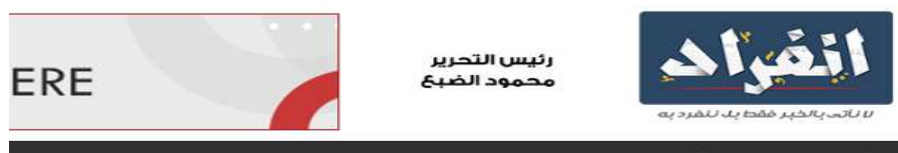

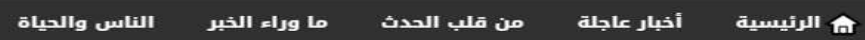

بالصور.. "انفراد" تكرم الساحر البرتغالى مانويل جوزيه

افتتاح أول مركز للموهوبين والتعليم الذكى غدا بكفر الشيخ

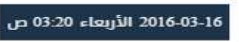

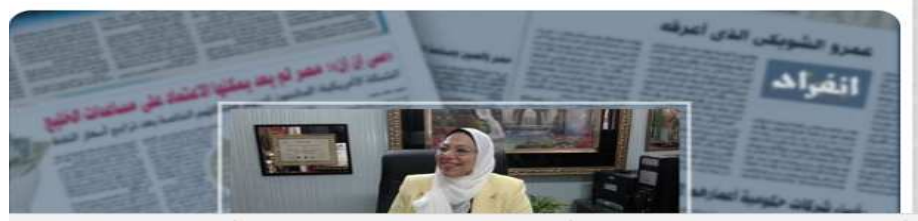

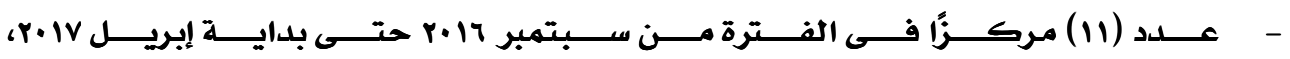
موزعة كالأتى : مولى

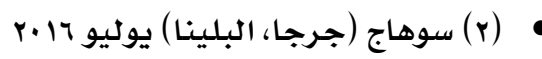

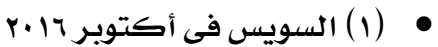

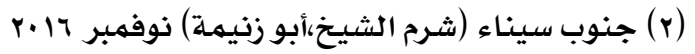

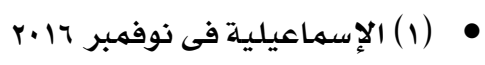

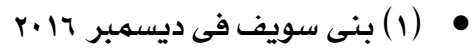

r.IV (1) القليوبية فى ابريل

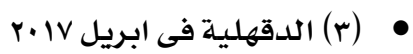



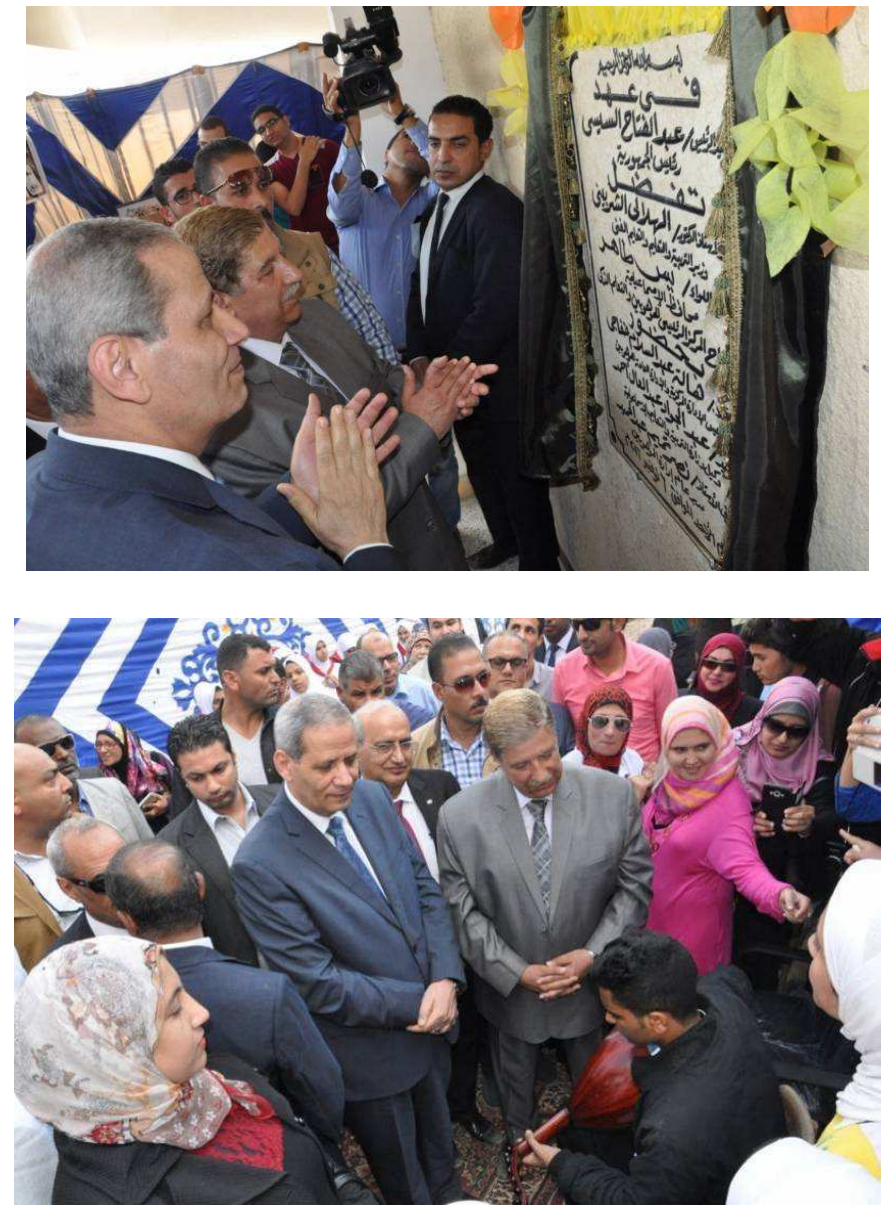

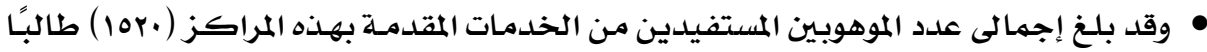
وطالبـة بكافة مراحل التعليم قبل الجامعي.

ب- رفع كفاءة مسئولى الموهوبين، وتطوير وتحديث طرق اكتشاف ورعاية الموهوبين؛ حيث تم :

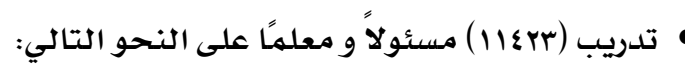

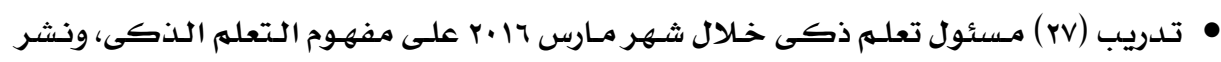
ثقافته.

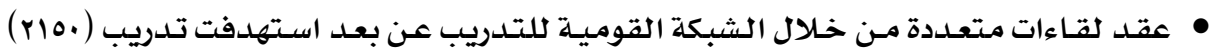

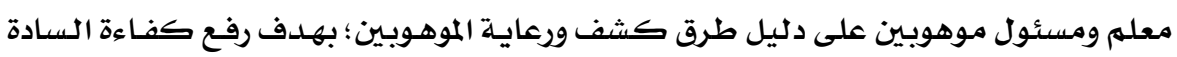

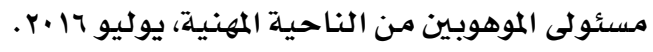


مجلة بحوث التربية النوعية - علدد .0 - ابريل r.11 ب ب

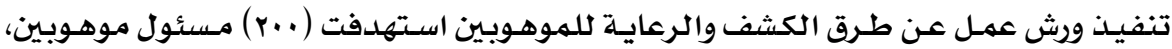

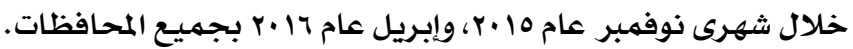

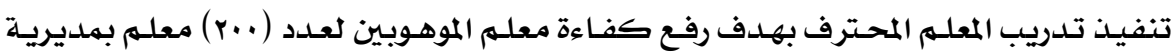

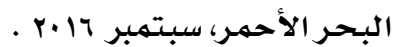

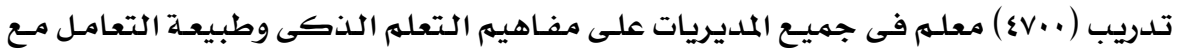

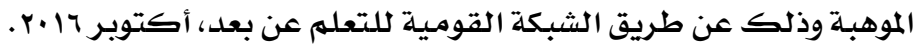

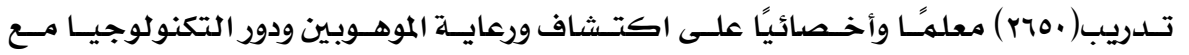

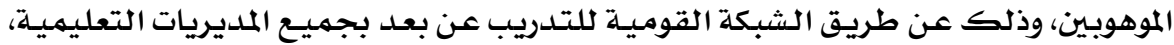

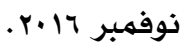

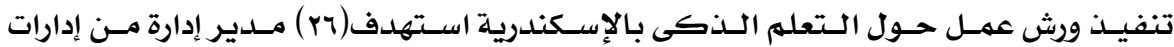

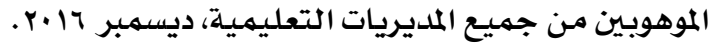

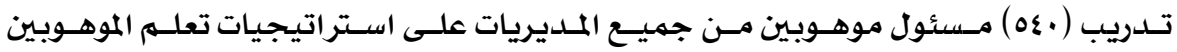

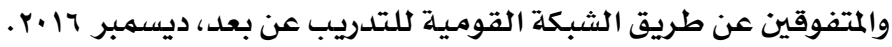

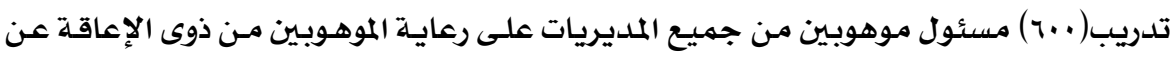

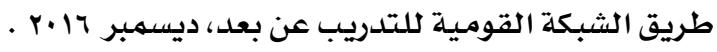
اعتماد أول حقيبة تدريبيـة للموهوبين بهصر مـن الأكاديميـة المهنيـة للمعلمـين عن أسـاليب

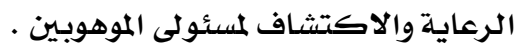

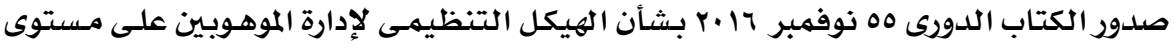
المديريات والإدارات التعليمية. • جـار إعـداد مسـروع قيـاس الاستعداد الأكـاديهى لـدى طـلاب الـصفين الثالث والسـادس مـن

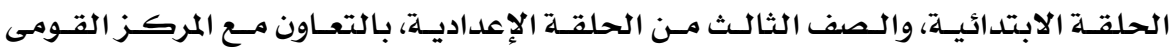

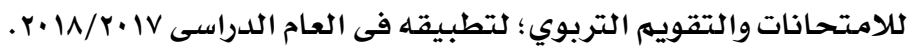

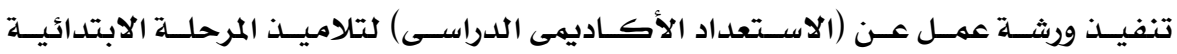
والإعدادية. • جار إعداد أول وثيقة قومية لاكتشاف ورعاية الموهوبين لتكون إطارًا عامَّا لاكتشاف ورعايـة

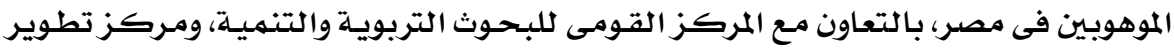
المناهج والمواد التعليميلة، والمركز القومى لملامتحانحانات والتقويهم التربوي. • طرح دليل للسادة مسئولى الموهوبين بالمديريات بعنـوان: "طرق الكشف والرعايـة للموهوبين"

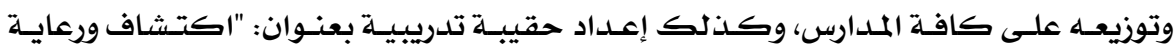

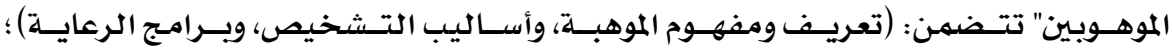
لاستخدامها فى تدريب مسئولى الموهوبين. 


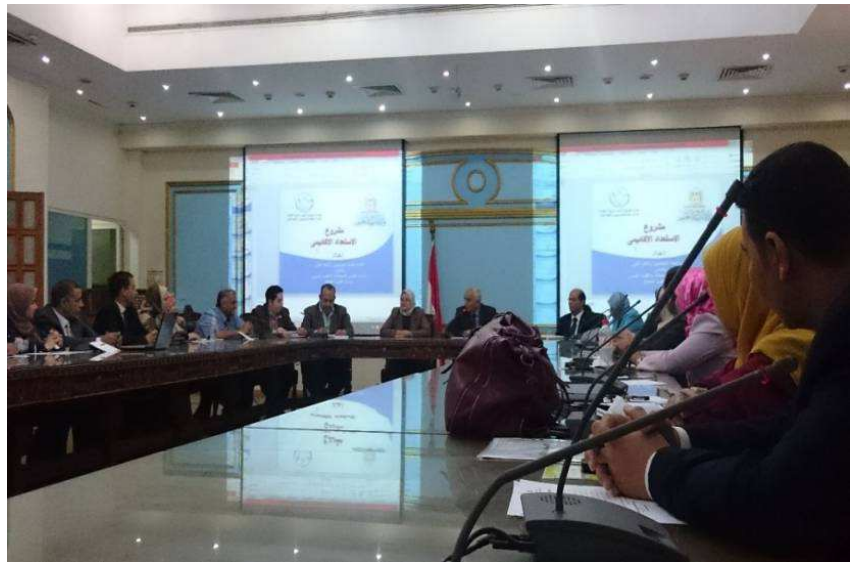

دعم الأنشطة التربوية للموهوبين؛ حيث تم :

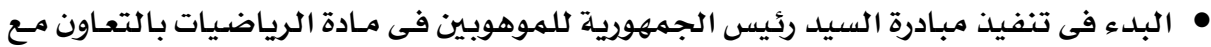
الكليـة الفنيـة العسسكريـة؛ حيـث تم توقيـع مـذكرة تفـاهم مـشتركة، وجـار إعــاد الإختبـار

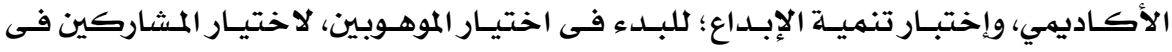
المبـادرة، بالإضـافة إلى عـرض لـبعض مـشـاريع الموهــوبين فـى الابتكــارات الرياضـية بهقـر الأكاديميـة الفنية العسكريـة.

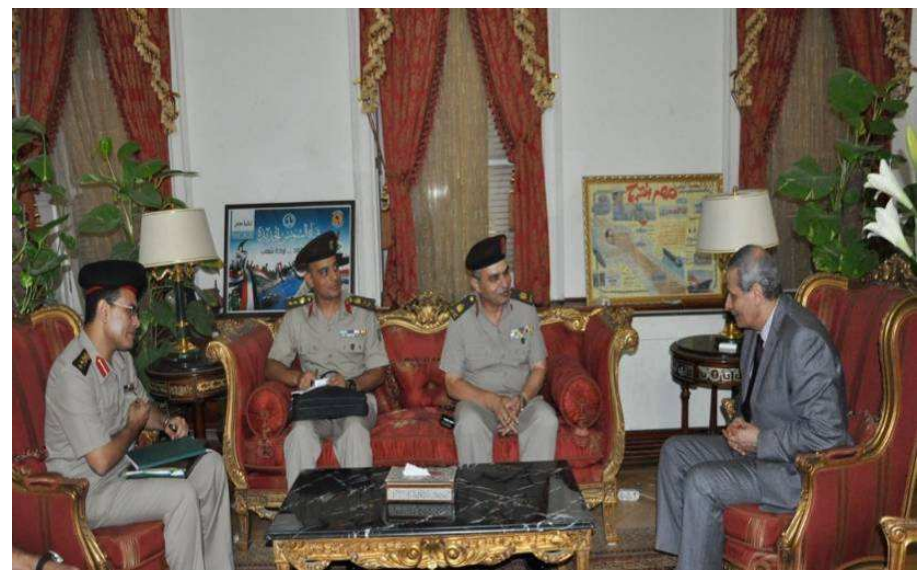

• مشاركة عدد(ع) مـن الطلاب الموهوبين بهلتقى الشارقة الثانى عشر بلدولـة الإمـارات العربيـة المتحدة ، و تمييزههم بشهادة تقدير، دون باقى الفرق المشاركة ، مارس 17 •r. . تنفيـذ ورث عمـل على تنهميـة مهارات الإبـداع، وكيفيـة عمـل صسحيفة إلكترونيـة لعـدد ( .00ه) طالبًا بهحافظة القاهرة، خلال إجازة نصف العام. تنفيـذ ورث عمـل لعـدد ( . .7) طالب مـن جميـع المحافظـات على مهارات التواصل مـع الآخـر، بالتعـاون مـع مشـروع التعليم أولاً. 
-

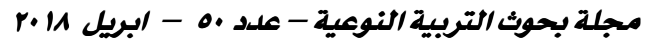

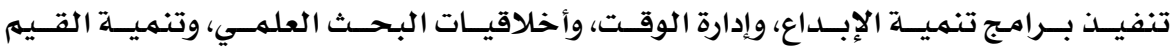
والأخلاقيـات لعدد ( . ع ) طالب من عدد(10) محافظة، خحلال فترة الإجـازة الصيفية. تشكيل لجنــة بـالتعـاون مـع أكاديهيـة البـحث العلهـي؛ لتقيـيم مبـتكرات ومخترعـات الطلاب الموهوبين، وتقديم الدعم الكلازم لهم.

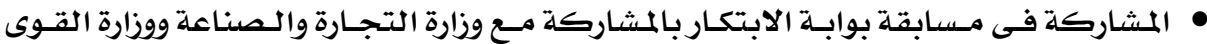

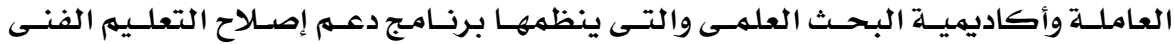
والتدريب المهنى TEVT II

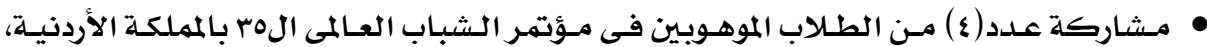
أغسطس 17 - 17. • مشاركة (طالب) من الطلاب الموهوبين فى مؤتثـر المنظمـة العالمية لتطوير الموهبـة فى ماليزيا بأغسطس 17 • و وحصولله على جائزة أفضل باحث لأفضل بحث فى المؤتمر، كمـا حصل على

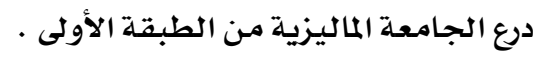
• طباعة وتوزيع النشـرة التوجيهية المنظمهة للعمل بالميدان وخطة العمل الخاصـة العام الدراسى

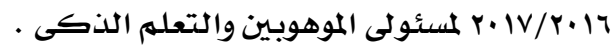

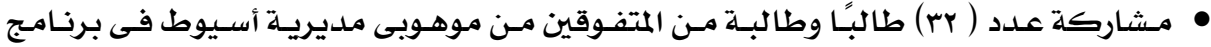
"العبـاقرة" والذى تنظمهـ وزارتا (التربيـة والتعليهم والشبـاب) بـالتنسسيق مـع مؤسسسات إعلاميـة

$$
\text { (القاهرة والناس) (واهرة) }
$$

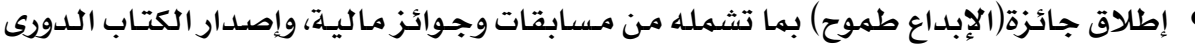

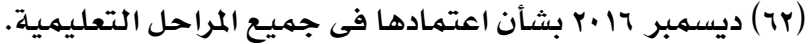

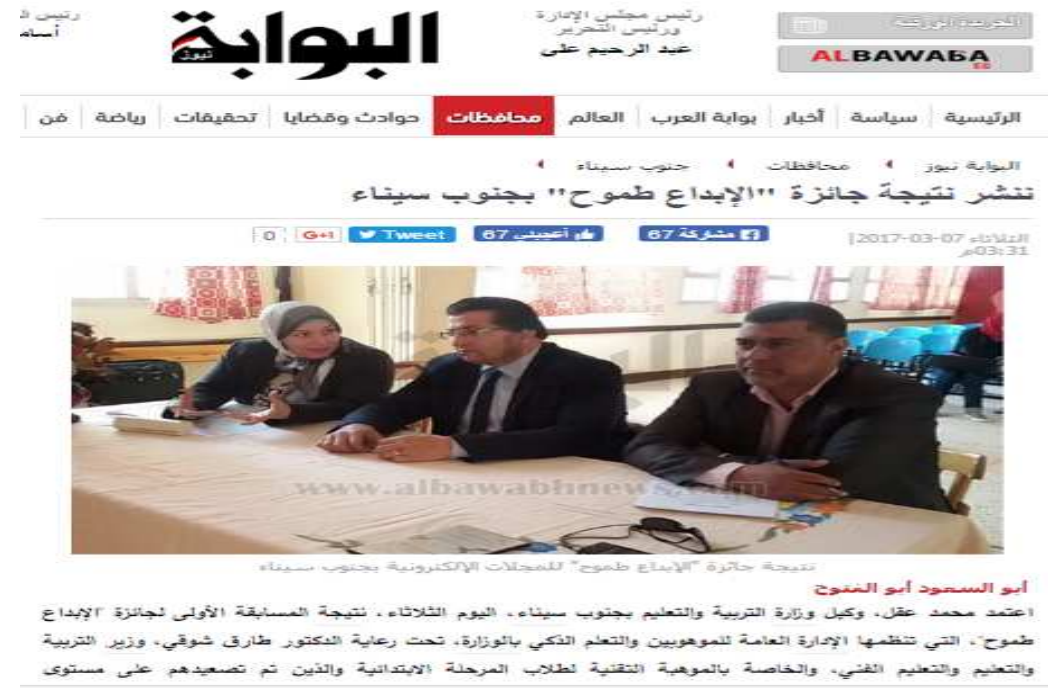




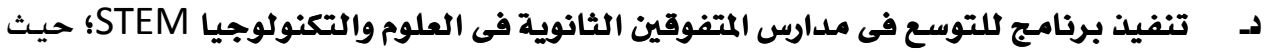

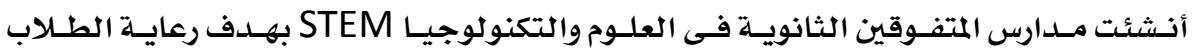

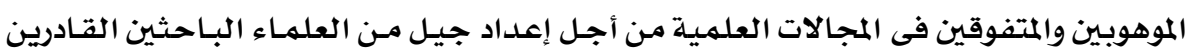

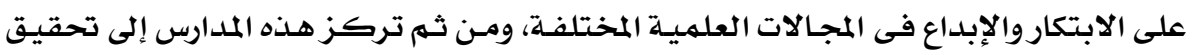
الأهداف التتاليـة: • رعاية الطلاب المتفوقين فى العلـوم والرياضـيات والهندسـة والتكنولوجيا مـن خـلال الاهتمـام

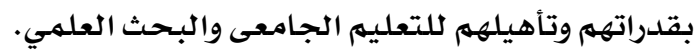

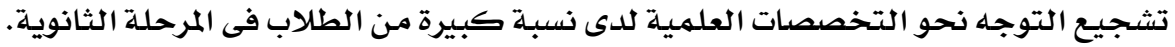

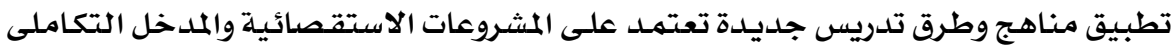
فى التدريس. ت تنمية ميول الطلاب نحو دراسة الرياضيات والعلوم

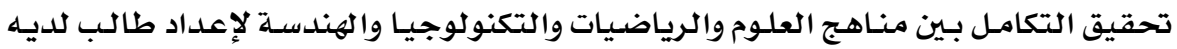

$$
\text { إكساب الطلاب مهارات التعلى التصميم والإبداع والتفكير النقدي. }
$$

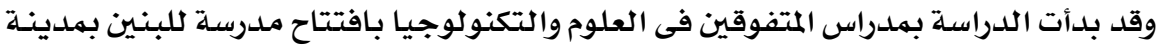

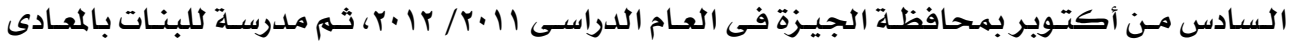

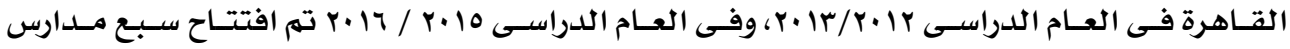

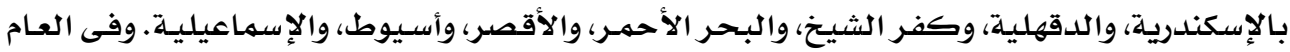

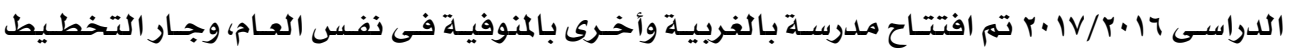

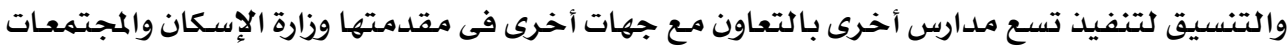

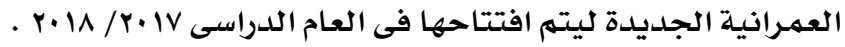

\section{• العملية التعليمية فى ملارس المتفوقين}

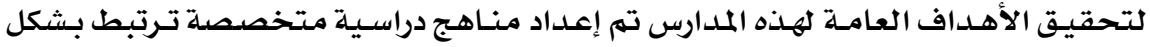

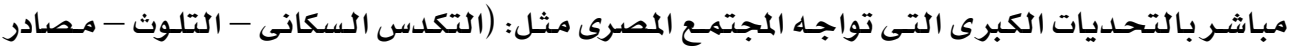

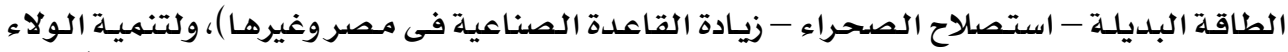

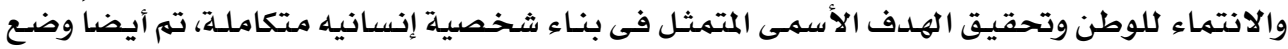

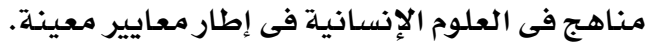

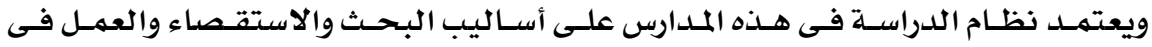

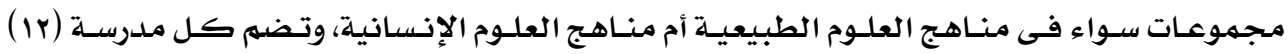

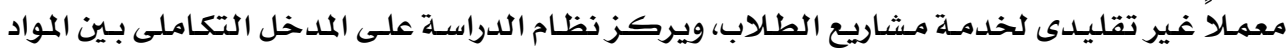

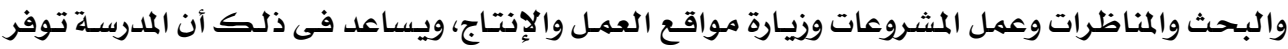


مجلة بحوث التربية النوعية - علد .0 - ابريل r.11
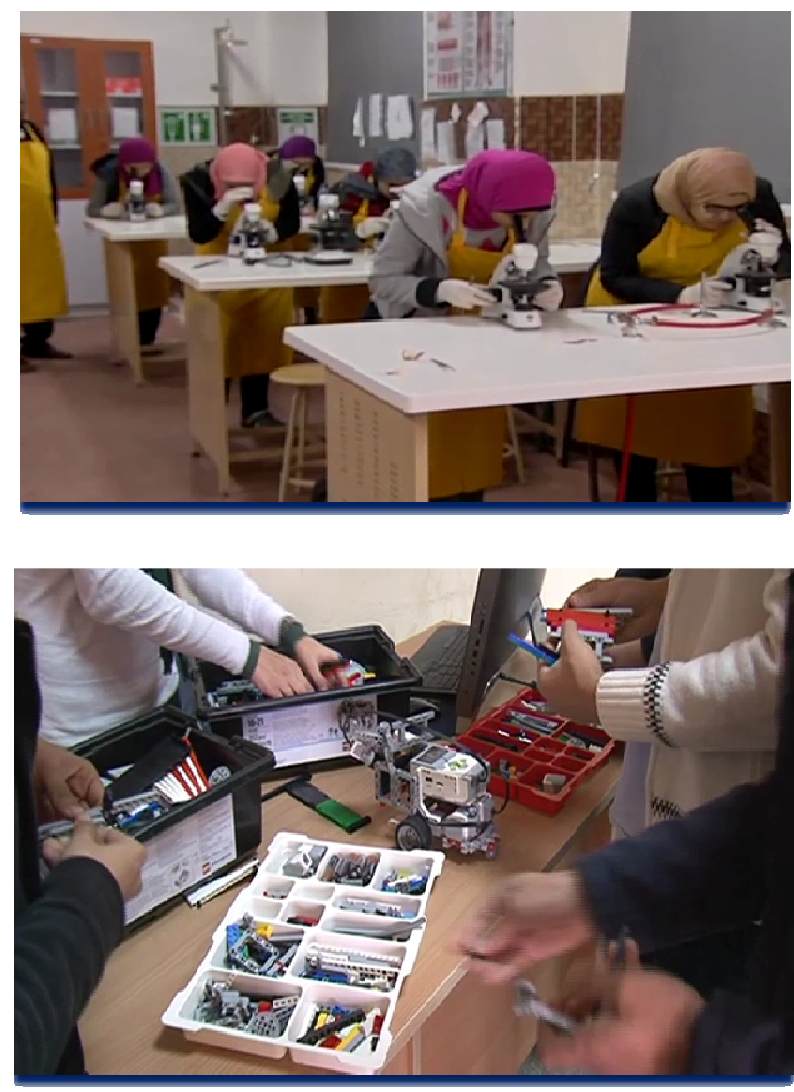

• مكونات ملارس المتفوقين

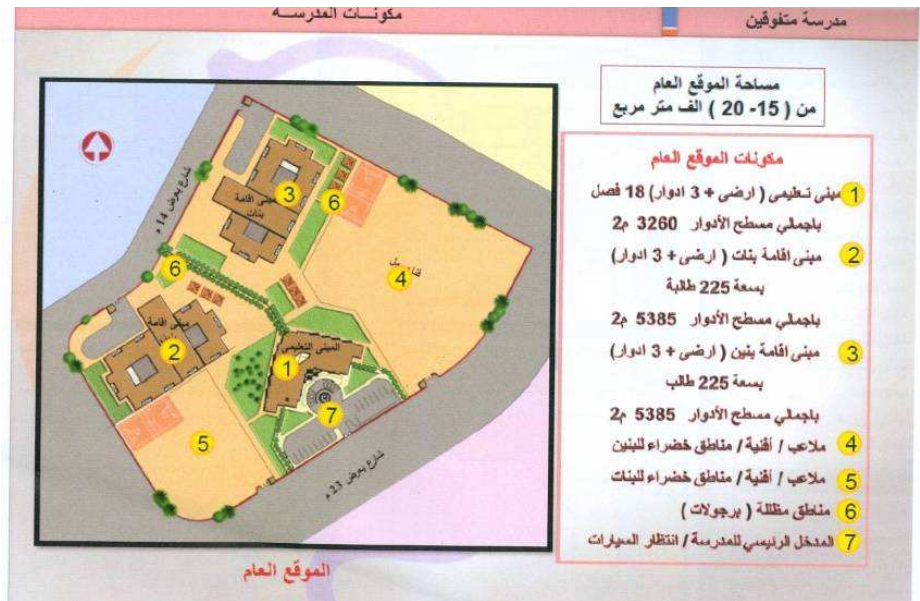


בبـ البرنامج الرابع : دعم ذوى الاحتياجات الخاصة من المعاقين والموهويين والفائقين
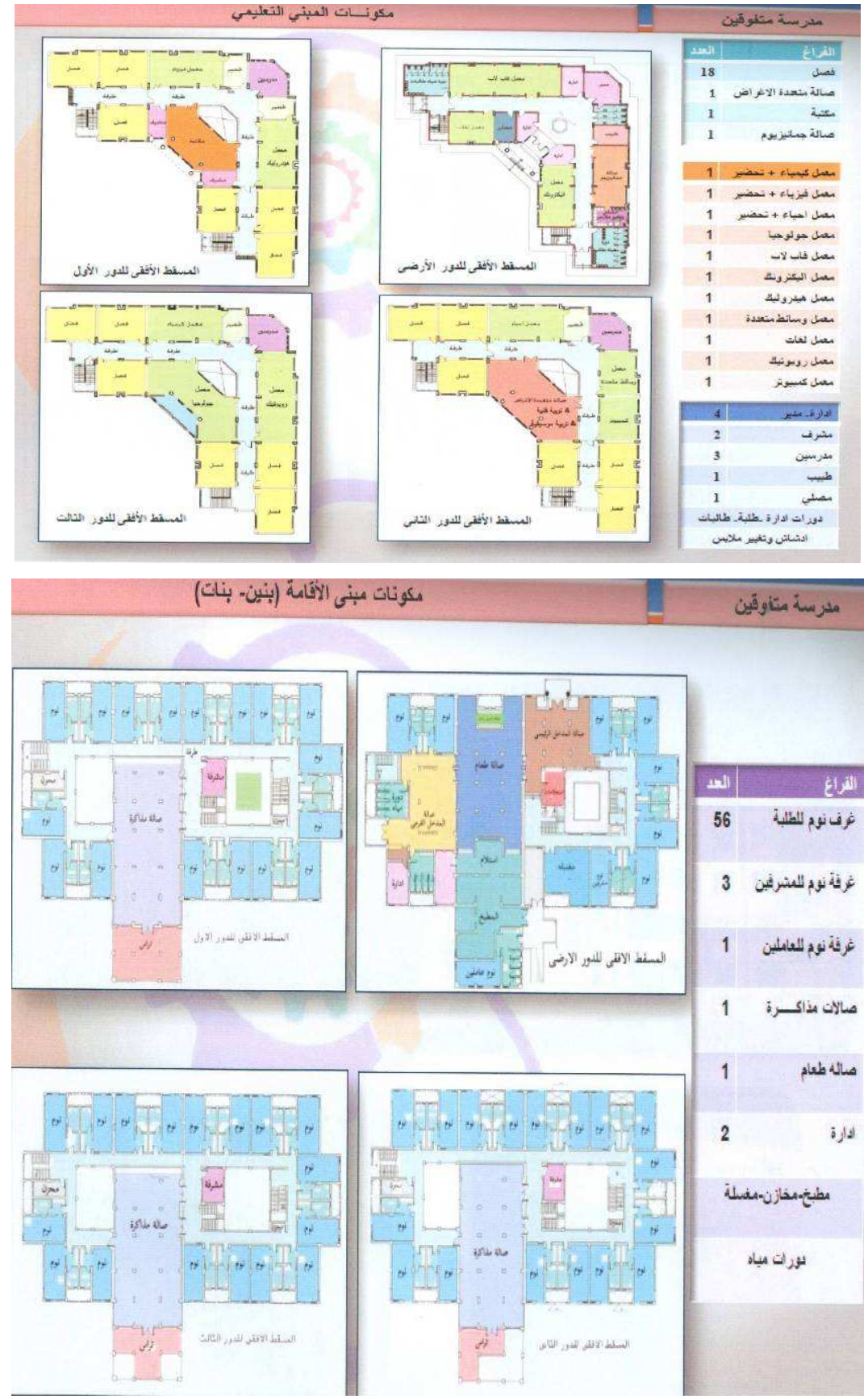


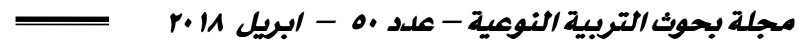
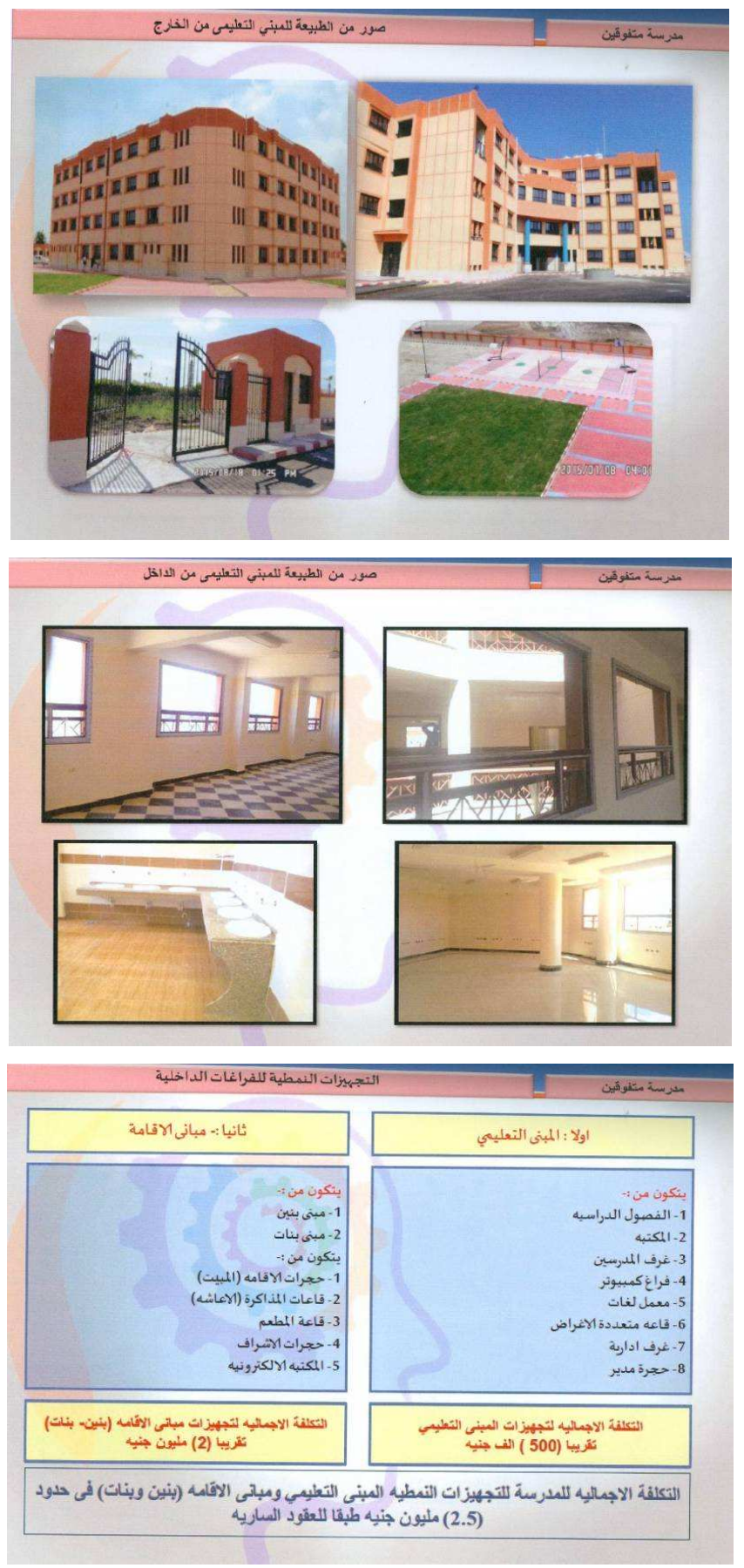

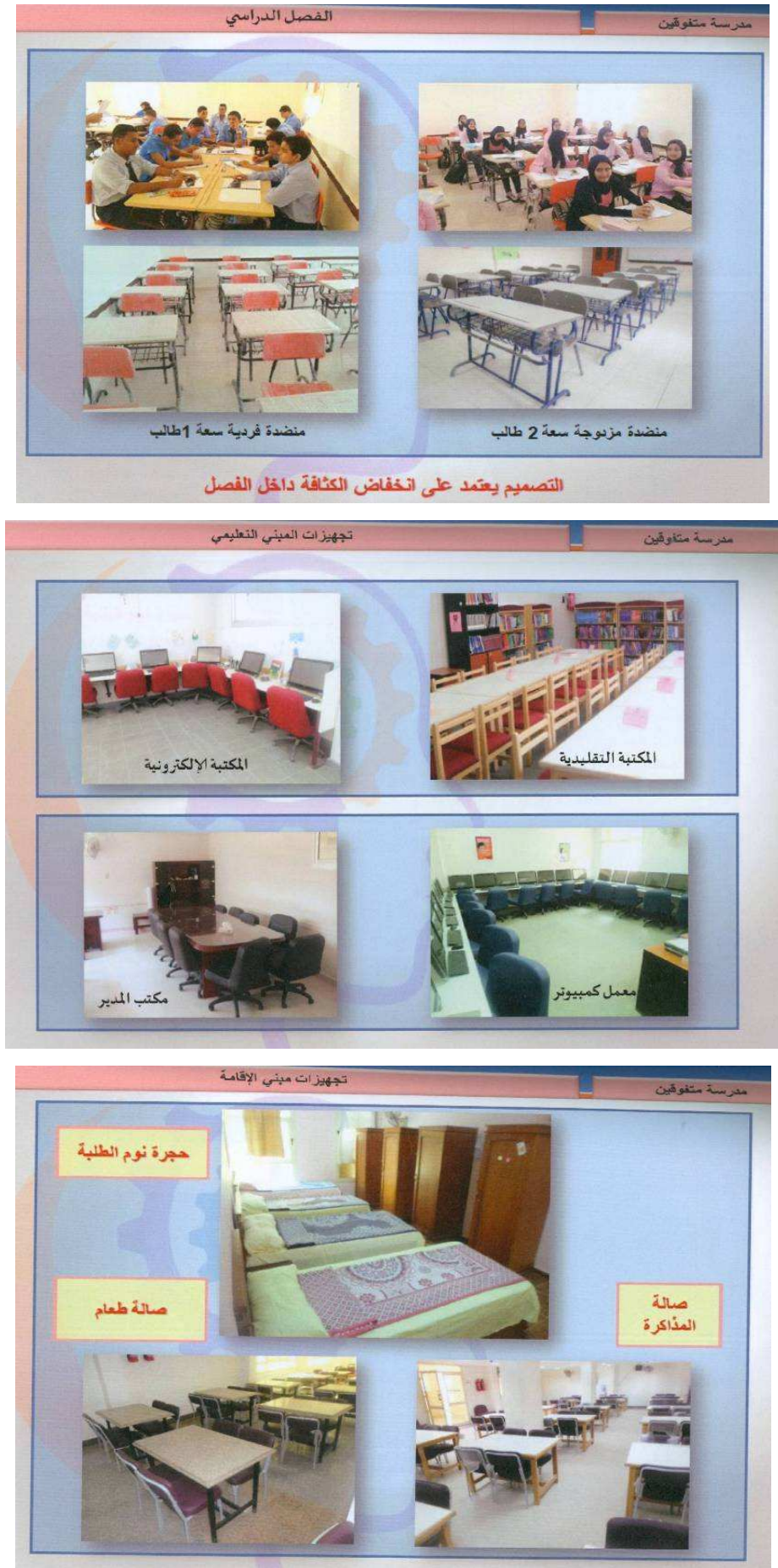

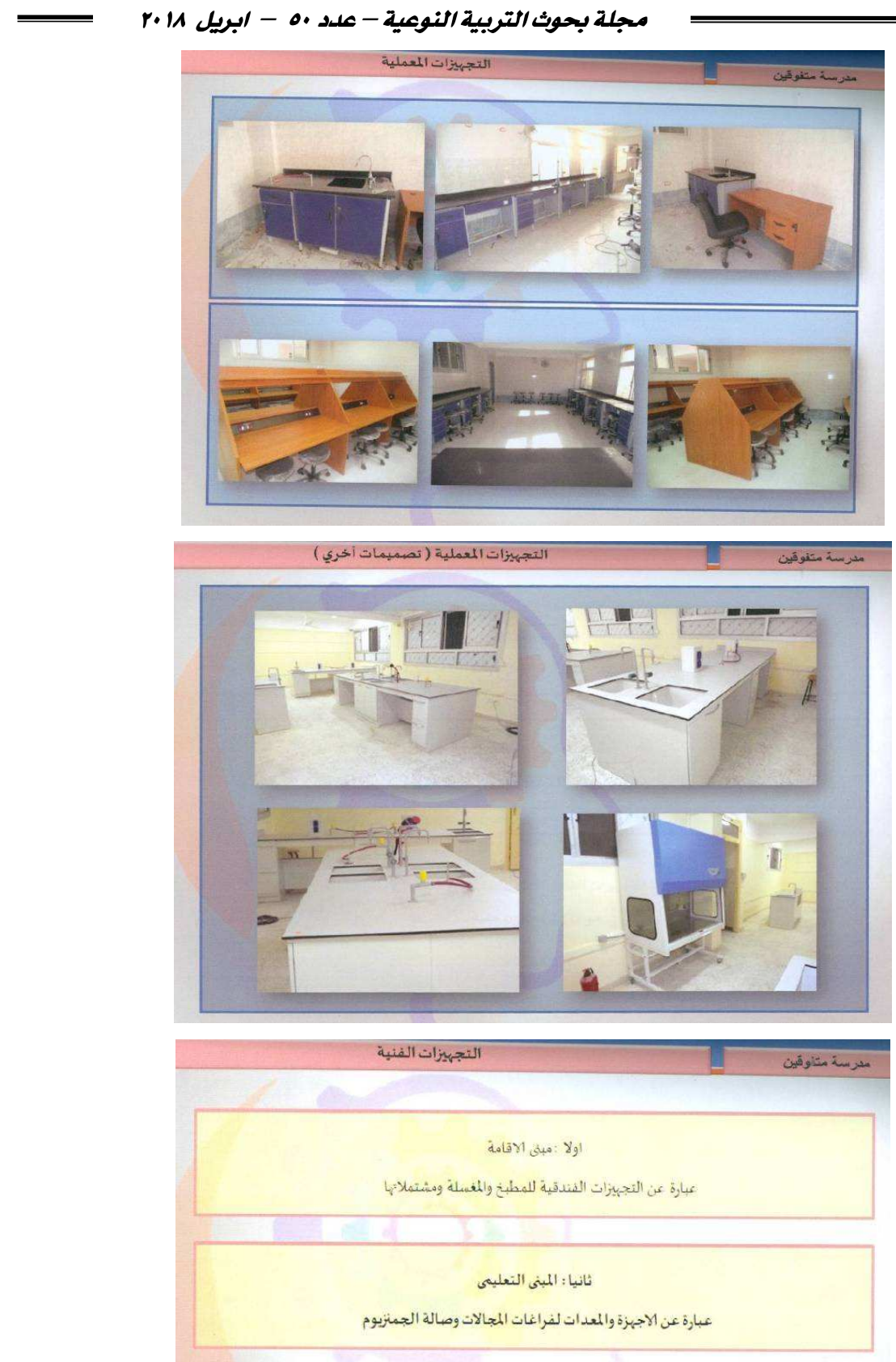

التكلفة النقديرية للتجهيبزات الفنية شاملة تكلفة المبنى التعليمى ومبنى الاقامة

حوالى (2 ) مليون جنية. 


\begin{tabular}{|c|c|c|c|c|}
\hline \multicolumn{5}{|c|}{ 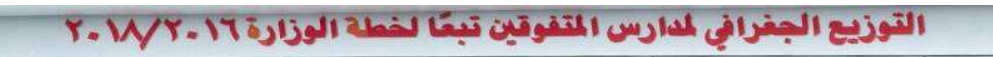 } \\
\hline ملاحظات & تاريخ بذء العمل & النطاق & المحافظة & م \\
\hline قاتم & $p+11$ & القاهرة (بنات فقطظ) & القاهرة (المعادي) & 1 \\
\hline مسترنف & $Y \cdot I N / r+1 Y$ & القاهزة & القاهرة & $r$ \\
\hline قانت & r.ir & الجيزة + الفيوم (بنين فقطظ) & الجيزة (العساد من أكتوبر) & $r$ \\
\hline مستهف & $Y \cdot \mid N / Y .1 V$ & الجيزة + الفيوم & الجيزة & 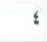 \\
\hline قانم & $r+19 / 4+10$ & الإسكندرية + مطروح & الإسكتلبرية & - \\
\hline قَانم & $p .18 / 4.10$ & الأقصر + أسوان & الأقصر & 1 \\
\hline قانم & $r .19 / 4.10$ & الإسماعيلية + بورسعيد & الإسماعيلية & v \\
\hline قَانم & $4.18 / 4.10$ & أسيوط + التوادي الجليد & أسيوط & $\wedge$ \\
\hline قانم & $p .19 / \%+10$ & البحر الأحمر + السويس & البحر الأحمر & 9 \\
\hline قُانم & $r .18 / 4.10$ & كفر الشُيخ + البحيرة & كنر الشيخ & 1. \\
\hline قانم & $r .17 / r+10$ & الدقهلية + دمياط & الدقهلية & 11 \\
\hline تحت الإنشاء & $r .18 / 4.17$ & المنوفية + القليوبية & المنوفية & ir \\
\hline تحت الإنشاء & $r .1 v / Y+19$ & الفربية & الغربية & ir \\
\hline مستهاف & $Y .1 N / Y+1 V$ & سوهاج + قَّا & سوهاج & $1 \leqslant$ \\
\hline مستوف & $Y, I N / Y, I V$ & المنبا +بني سويف & المنبا & 10 \\
\hline مستهنف & $Y \cdot 1 N / Y+1 Y$ & جنوب وشُمال سيناء & جنوب سيناء & 14 \\
\hline مسنهات & $r+1 N / r+1 V$ & الشرقية & الشرقية & iv \\
\hline
\end{tabular}

\section{آليات القبول بمدارس المتفوقين}

تقبل مدارس المتفوقين الثانوية فى العلوم والتكنولوجيا الطلاب الناجحين فى شهادة إتمام

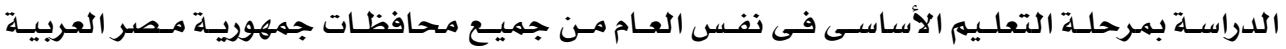

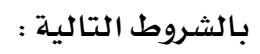

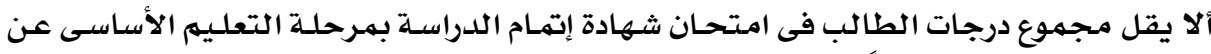

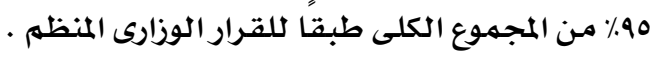

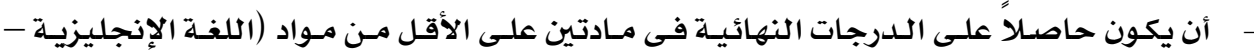

$$
\text { الرياضيات - العلوم). }
$$

- أن يجتاز اختبار التفكير الإبداعى النوعى فى العلوم والرياضيات والهندسة والتكنولوجيا. - أن يجتاز الكثف الطبى بالتأمـين الصحى في الإدارة التابع لها المدرسية.

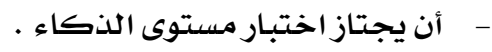

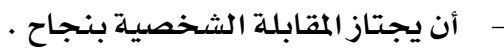

$$
\text { تقويم الطلاب في مدارس المتفوقين }
$$

يحصل الطالب على مجموع اعتبارى فى ضوء أربعة مؤشرات، كالآتي: 
- اختبار الاستعداد للقبول بالجامعات (U.R.T).

- مقاييس للمفاهيم التى كونها الطلاب فى العلوم والرياضيات.

- أداء الطلاب فى المشروعات (CAPSTONE).

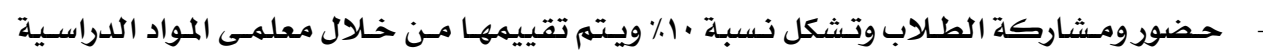

المختلفة تحت إشراف مديرى المدارس.

ويشترط لنجاح الطالب الحصول على . ٪٪ فى كل مكون من المكونات الأريعة.

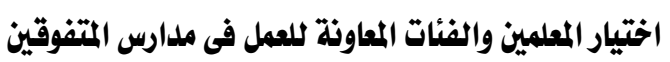

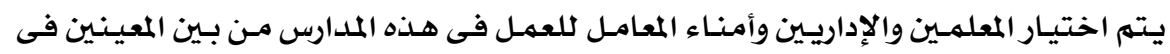

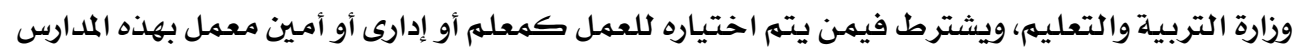

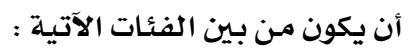

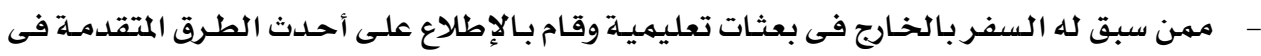

$$
\text { التدريس. }
$$

من الحاصلين على درجة الماجستير أو الدكتوراه.

- من ذوى الكفاءة المتميزة فى التدريس من المدارس الرسمية أو الرسمية المتميزة للغات.

ممن تتوافر لديهم الإجادة التامة للغة الإنجليزيلة.

$$
\text { من يجتازون التدريب المطلوب. }
$$

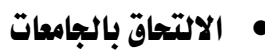

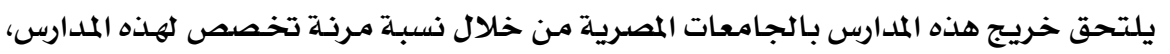

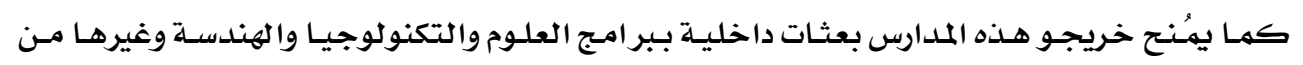

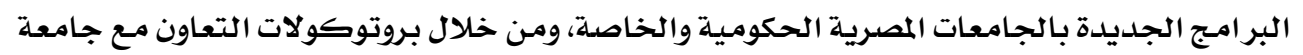

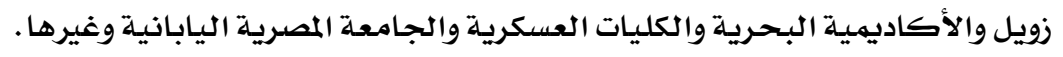

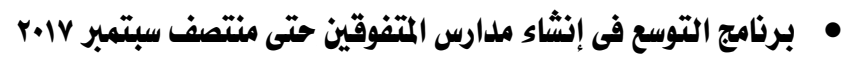

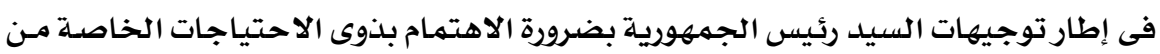

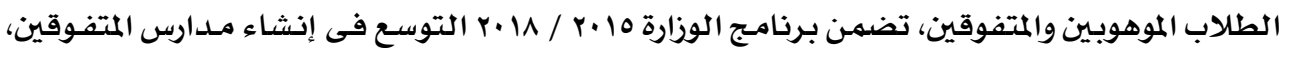

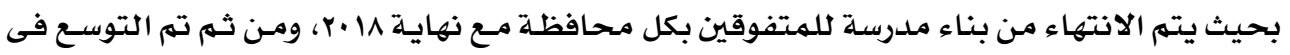

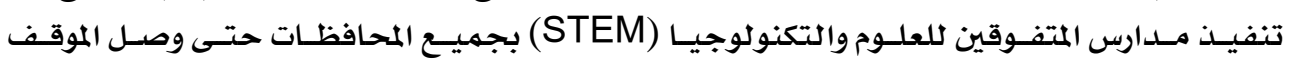

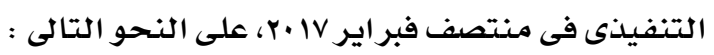

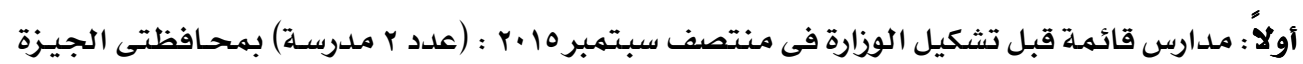
والقاهرة. 


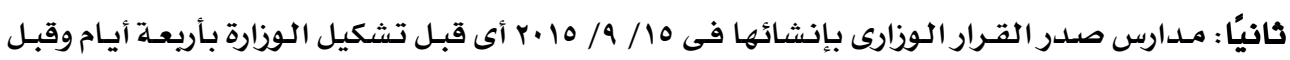

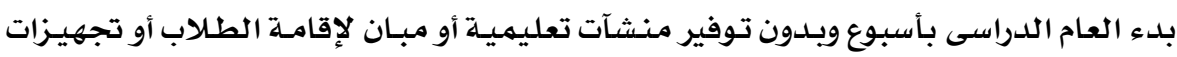

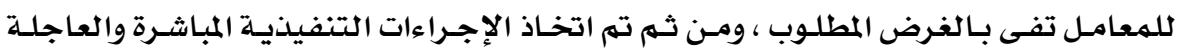

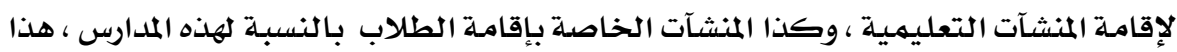

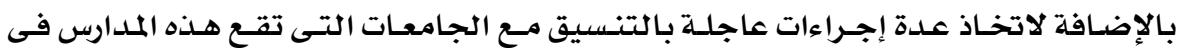

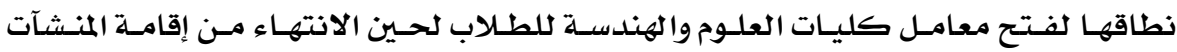

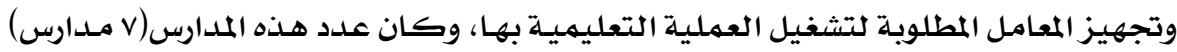

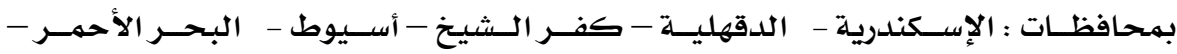

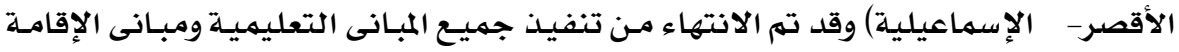

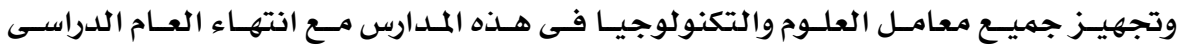

$$
r+17 / r+10
$$

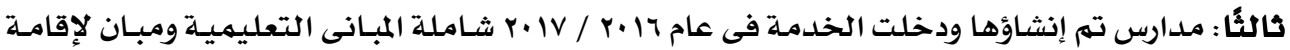

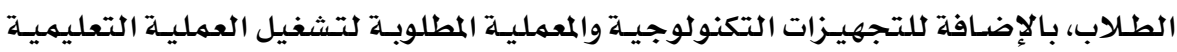

$$
\text { وعددها مدرستان بالغربية والمنوفية. }
$$

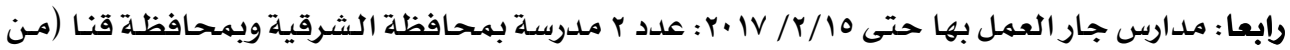

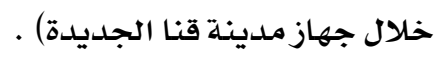

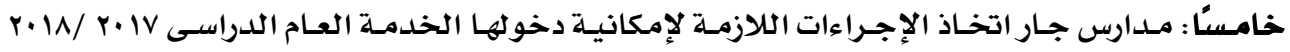

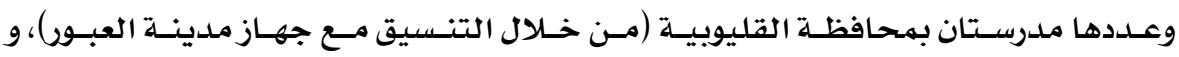

بمحافظة بنى سويف (حيث تم توفير المبنى التعليمى وجار الطرح لإنشاء مبنى الإقامـة).

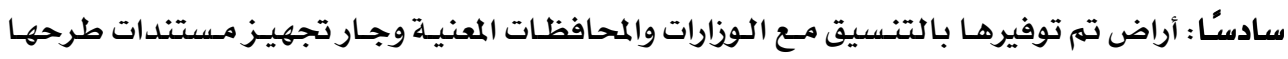

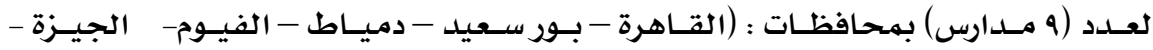

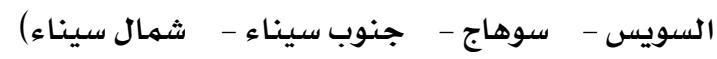




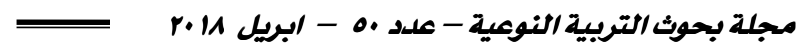

• تخريج دفعة من ملارس المتفوقين
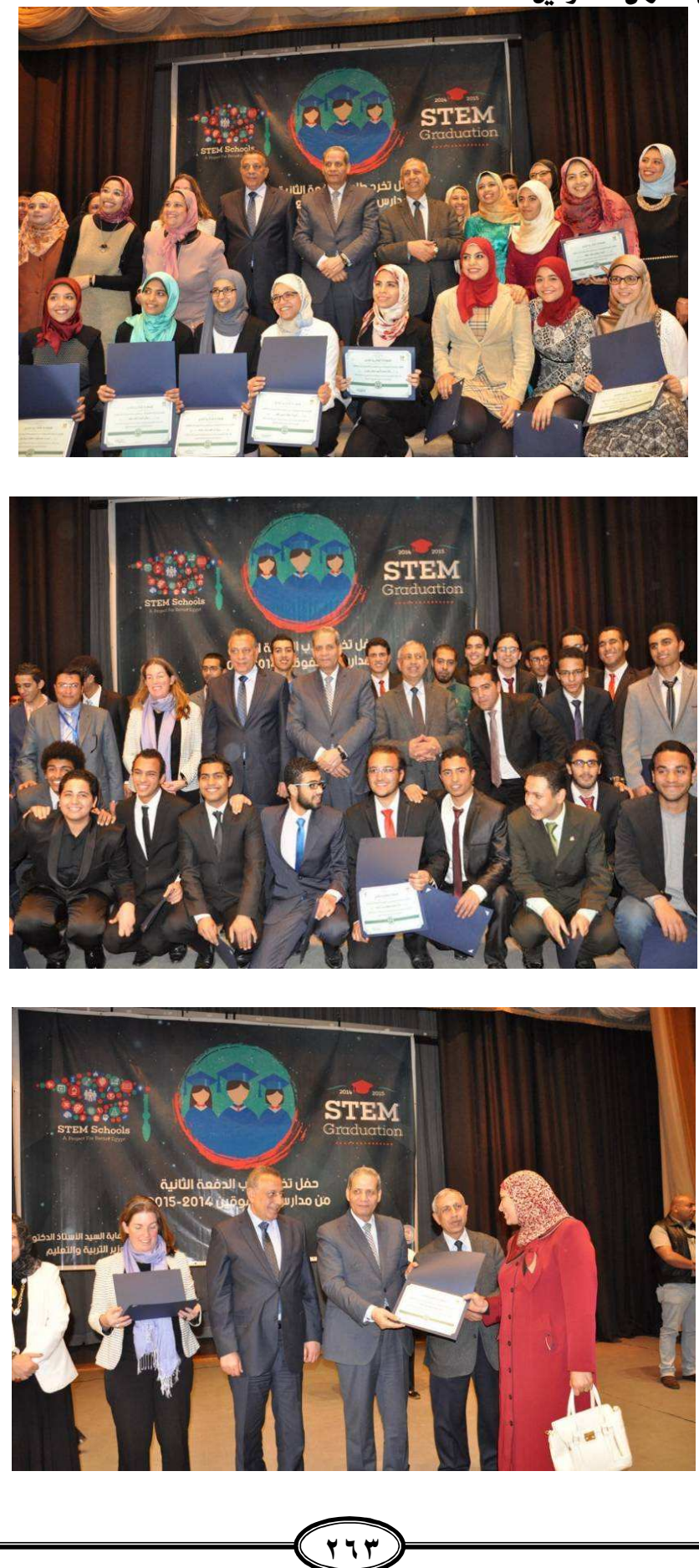


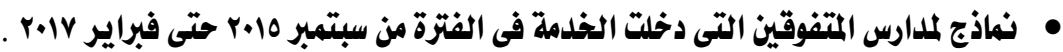
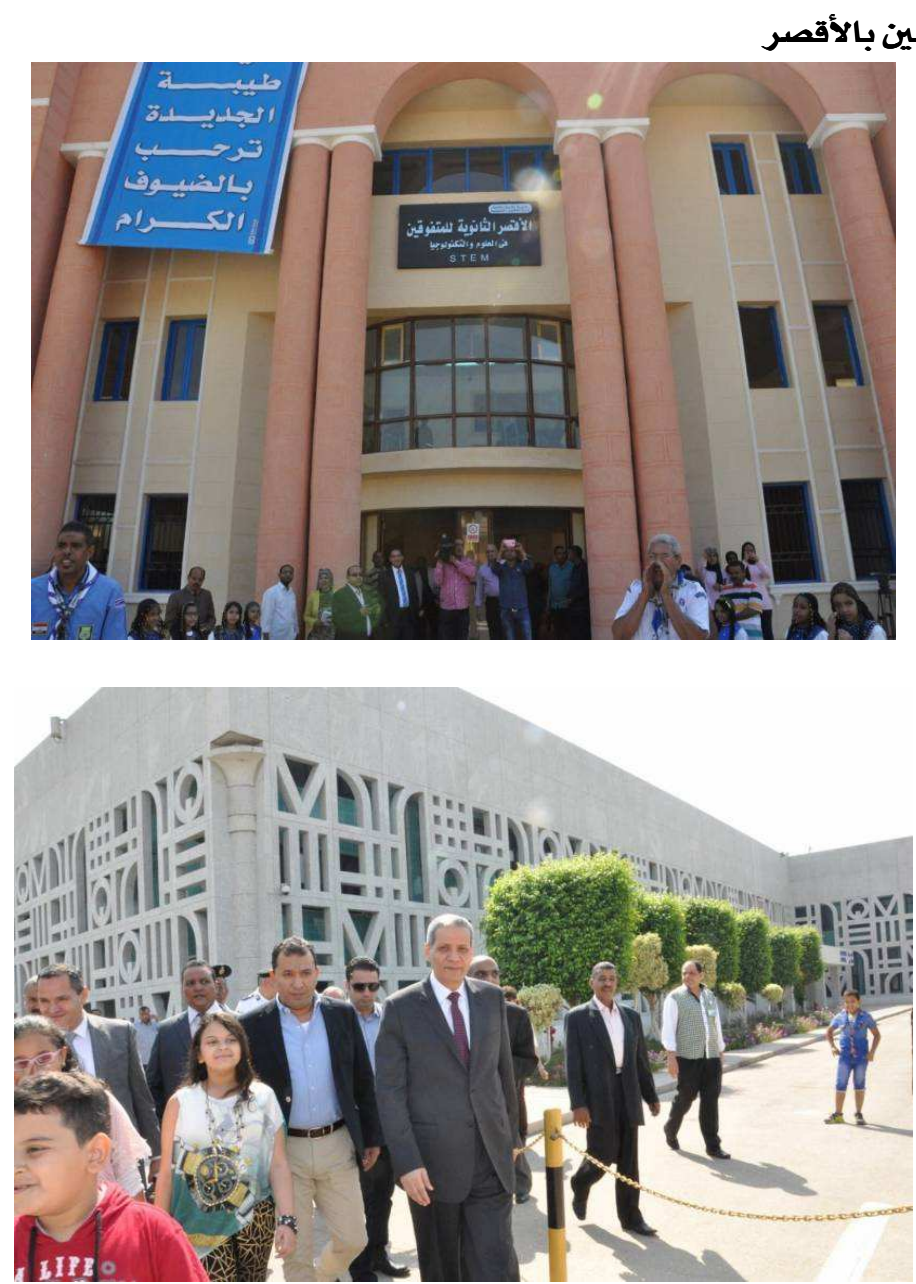

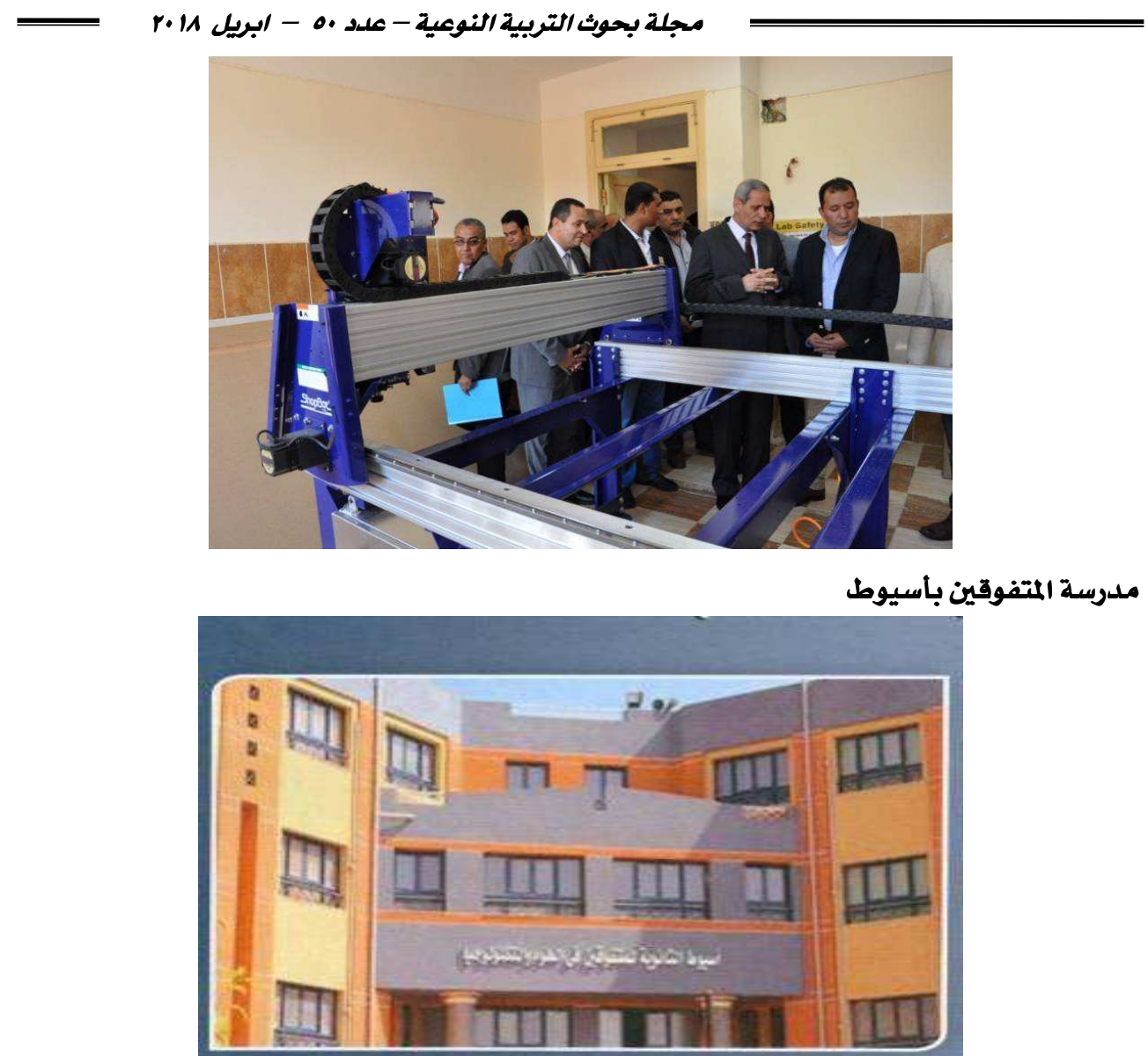

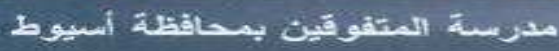

مدرسة المتفوقين بالغردقة بالبحر الأحمر

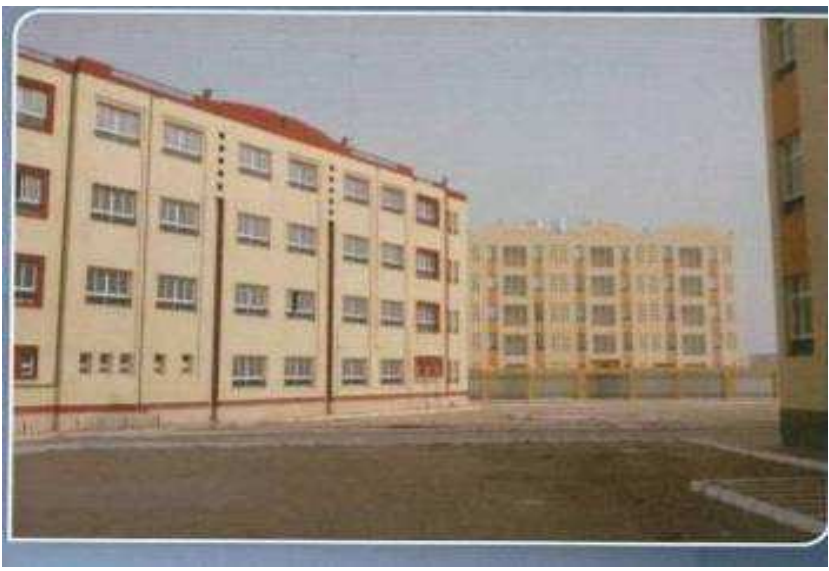




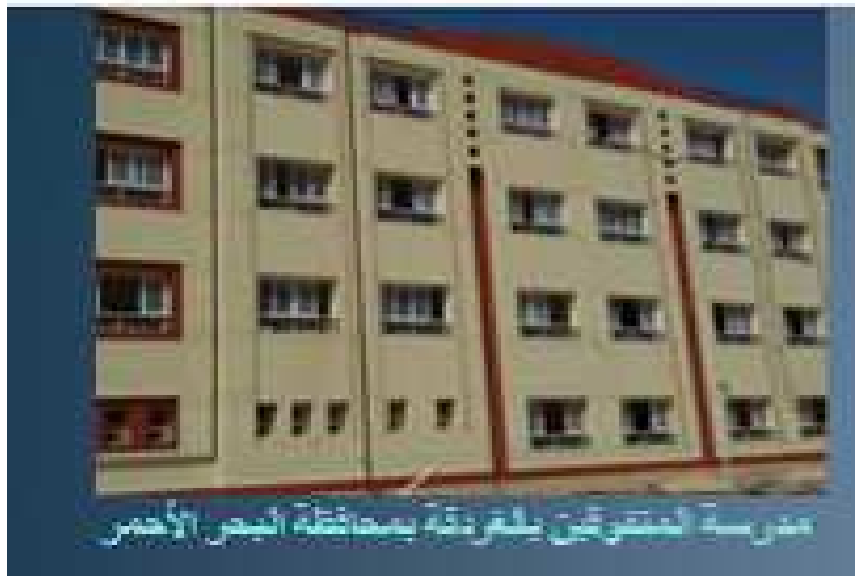

مدرسة المتفوقين بجمصة بالدقهلية

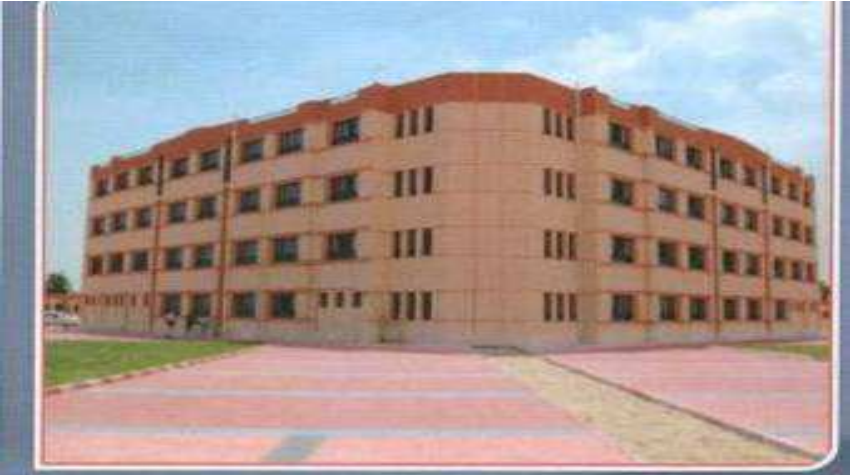

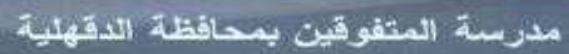

مدرسة المتفوقين بكفر الشيخ

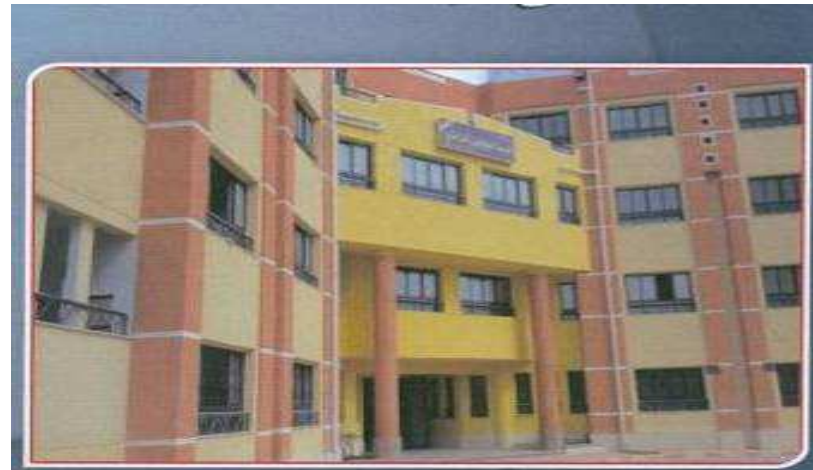

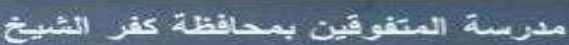


مدرسة المتفوقين ببرج العرب بالأسكندرية

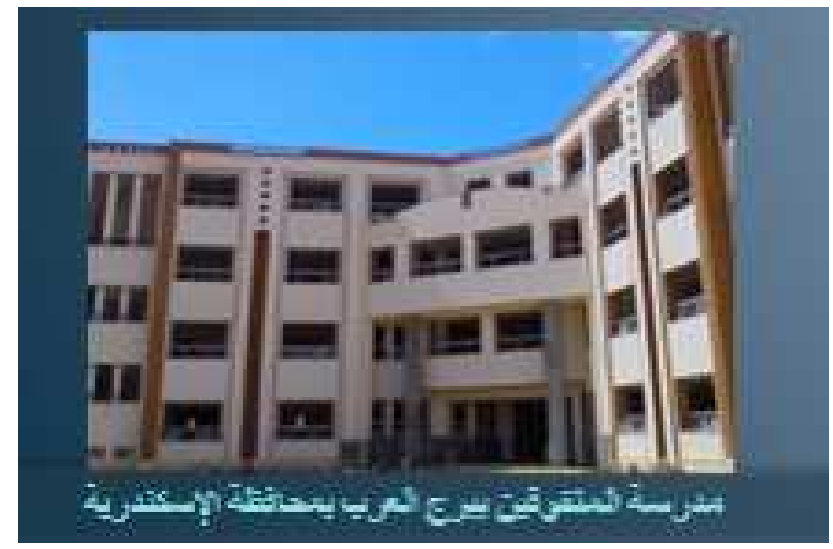

مدرسة المتفوقين بالإسماعيلية
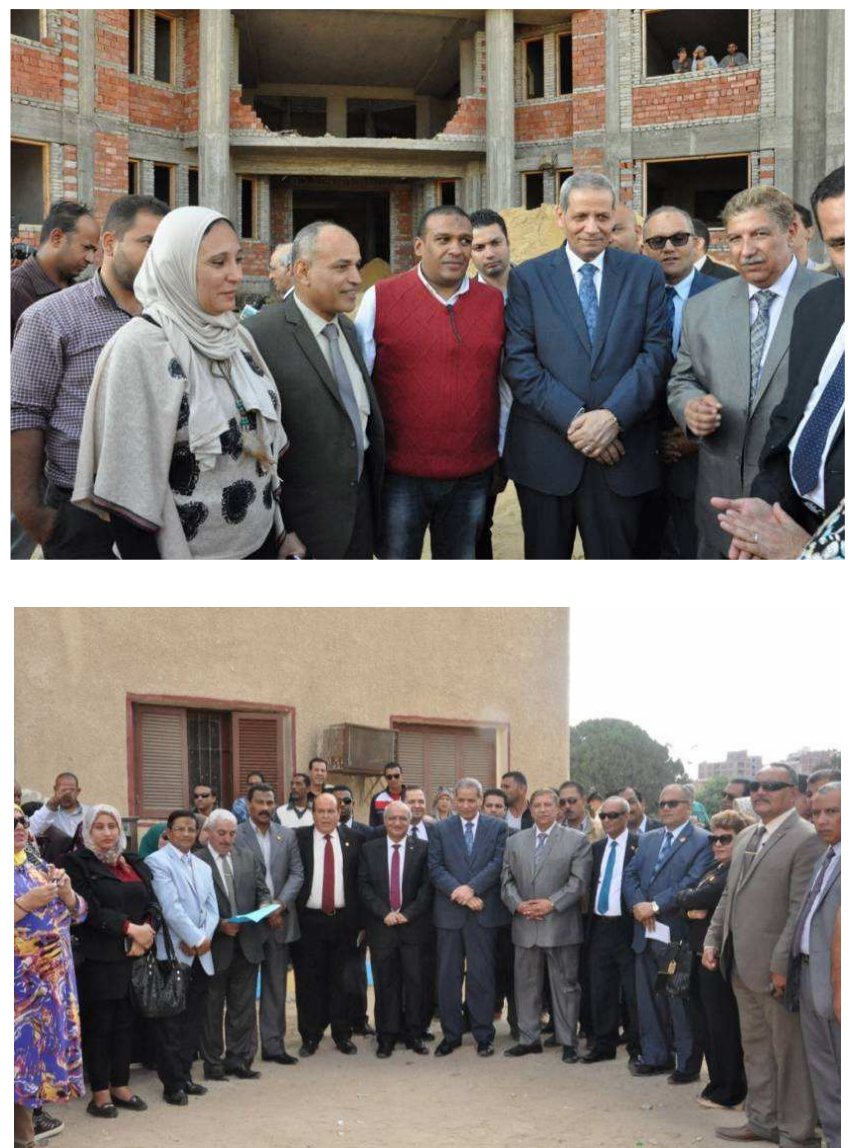


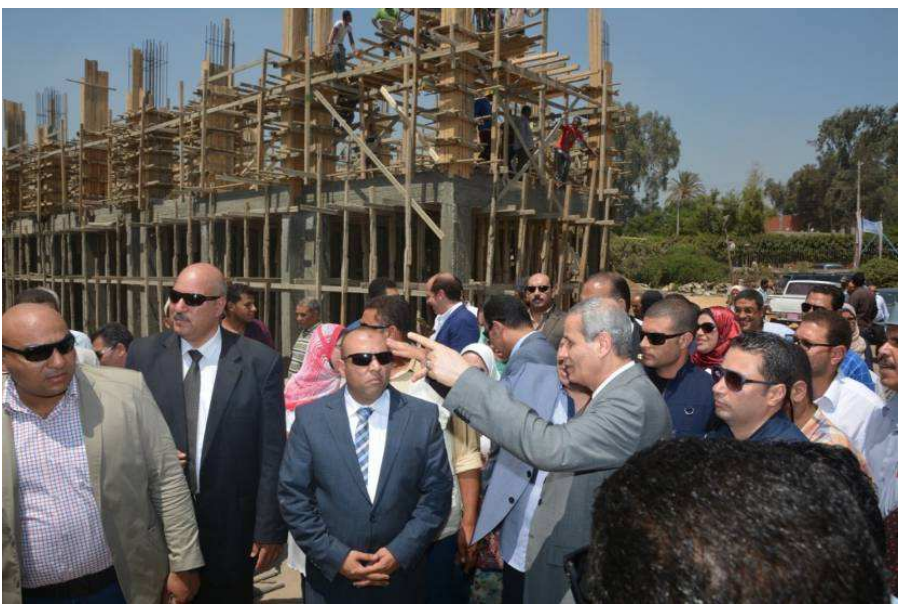

خاتمــــــة

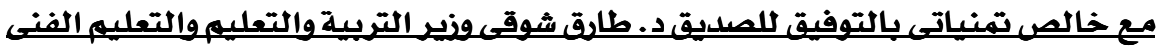

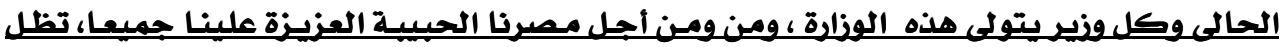

الأسئلة التالية تطرح نفسها

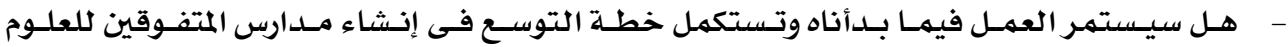

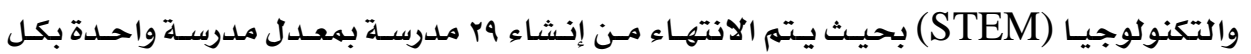

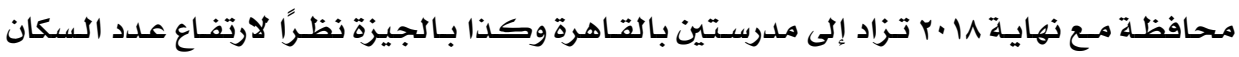
بهما

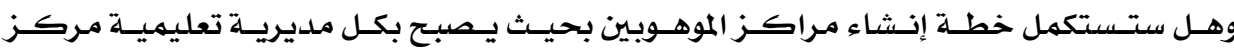

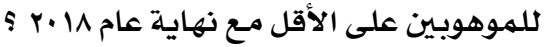

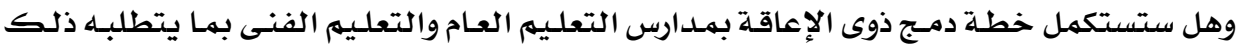

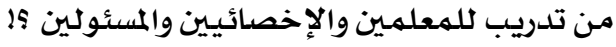

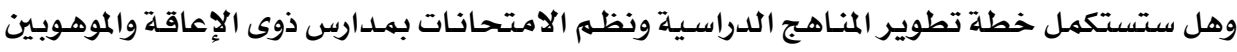

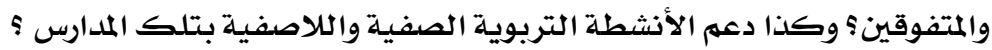
هذا ما نتمناه فى ظل القيادة الحكيمة للسيد الرئيس عبد الفتاح السيسى حفظه الله 


\section{الهواهش والمراجع}

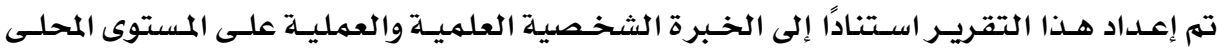

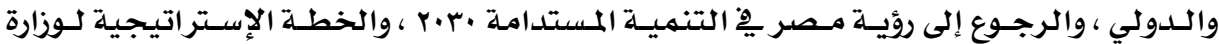

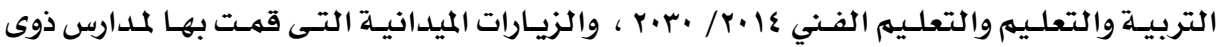
الاحتياجـات الخاصة على الطبيعة، وكذا اللقاءات والاجتماعات التى عقدتها، والاتفاقيات التى وقعتهـا بشأن هـذه الفئـات مـن الطـلاب، بـالإضـافة للتقـاريـر التى قدمت لنـا حـول تطـور الأوضـاع وتطوير العهل مـع هـذه الفئكات ، والتقـارير الـواردة مـن الإدارة المركزيـة للتربيـة الخاصسة، والهيئسة

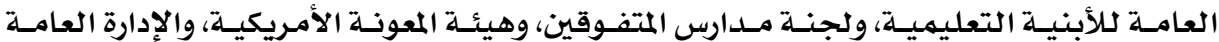
للـموهـوبـين والـتعلم الـذكى، و المكتـــ الفنـى للـوزيـر، والقطاعـات والإدارات والمراكـز البـحثيـة التابعـة للوزارة، و بصفة خاصـة السيد اللواء مهندس/ يسـرى سـا لم رئيس هيئة الأبنيـة التعليميـة

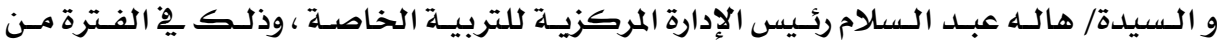

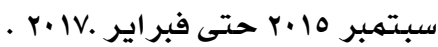

جيهـان كمـال (محـرر) : مـشكلات التعلـيهم قبـل الجـامعى وآليـات مقترحسة لمواجهتهـا، المركـز

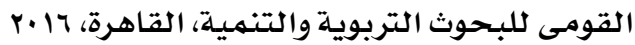

